\title{
Schwartz Değerler Sistemi Kapsamında Turist Davranışlarının Değerlendirilmesi: İstanbul Örneği
}

\author{
Oğuz ÇAM ${ }^{1}$ ve Muharrem AVCI ${ }^{2}$
}

\section{$\ddot{O} z$}

Bu çalışmanın temel amac1; Schwartz değerler sistemi çerçevesinde turist davranışlarını incelemektir. İstanbul, turistik açıdan önemli bir çekim noktası olduğu için bu çalışmada ön plana çıkarılmak istenmiştir. Turist memnuniyetinin daha fazla elde edilmesi açısından turist davranışlarının kişisel değerler çerçevesinde saptanması önemli olarak görülmektedir. Kişisel değerlerin, turist davranışlarında çok etkili olduğu, bu alana dikkat çekmenin farklı bir izlenim (olumlu olarak) oluşturacağı ve farkındalık yaratacağı ifade edilmektedir. Bu araştırma, turist davranışlarının kişisel değerler odaklı olarak hem sosyolojik, hem kültürel, hem de turistik açılardan değerlendirilerek turist davranışlarının farklı yönlerden anlaşılmasına olanak sağlamaktadır. Araştırmanın metodu; nitel araştırma metodu, araştırmanın veri toplama aracı; doküman analizi tekniği, veri analiz tekniği ise; betimsel analiz tekniğidir. Bu araştırmada turistlerin davranışlanı incelenirken Schwartz değerler sistemindeki toplamda 10 gruba ayrılan kişisel değerler göz önünde bulundurularak bir inceleme işlemi yapılmıştır. Sonuç olarak; turistlerin düşünce, davranış, duygu ve tutumlarının net bir şekilde anlaşılması, turistlerin memnuniyet ve sadakatinin sağlanmasinda önemli olarak görülmektedir.

\section{Anabtar Kelimeler: Kişisel Değerler, Turizm, Turist Davranışları}

Assessment of Tourist Behaviors within the Scope of Schwartz Values System: The Case of Istanbul

\begin{abstract}
The main purpose of this study is; to examine tourist behavior within the framework of Schwartz value system. Since Istanbul is an important tourist attraction point, it is wanted to be highlighted in this study. In order to achieve more tourist satisfaction, it is important to determine tourist behaviors within the framework of personal values. It is stated that personal values are very effective in tourist behavior, drawing attention to this area will create a different impression (positively) and create awareness. This research enables the understanding of tourist behavior from different aspects by evaluating tourist behaviors from both sociological, cultural and touristic perspectives with a focus on personal values. The method of the research; qualitative research method, data collection tool of the research; document analysis technique, data analysis technique; it is a descriptive analysis technique. In this study, while examining the behavior of tourists, a study was carried out by considering personal values divided into 10 groups in total in the Schwartz value system. As a result; a clear understanding of the thoughts, behaviors, feelings and attitudes of tourists is seen as important in ensuring the satisfaction and loyalty of tourists.
\end{abstract}

Key Words: Personal Values, Tourism, Tourist Behaviors

\section{Atıf İçin / Please Cite As:}

Çam, O., Avcı, M. (2021). Schwartz Değerler Sistemi Kapsamında Turist Davranışlarının Değerlendirilmesi: İstanbul Örneği. Manas Sosyal Araştırmalar Dergisi, 10(3), 2037-2059.

Geliş Tarihi / Received Date: 10.12.2020

Kabul Tarihi / Accepted Date: 16.04.2021

\footnotetext{
1 Yüksek Lisans Öğrencisi - Kastamonu Üniversitesi Sosyal Bilimler Enstitüsü, oguzcam911@gmail.com

iD ORCID: 0000-0003-3222-3367

2 Dr. Öğr. Üyesi - Kastamonu Üniversitesi Turizm Fakültesi, mavci@kastamonu.edu.tr

iD ORCID: 0000-0002-0264-1181
} 


\section{Giriş}

Turizm sektöründe en sık görülen problemlerin turistler ile turizm personeli arasında geçtiği tahmin edilmektedir. Bu durum, turizm etkinlik ve aktivitelerinin gerçekleştirilmesinde oldukça belirleyici olmaktadır. Turistlerin birtakım istek ve gereksinimlerinin yerine getirilememesi ya da eksik yerine getirilmesi, etik ve ahlaki değerlere sayg1 gösterilmeyip bunların hiçe sayılması, iletişim sorunları gibi durumlar turizm hareketlerini sekteye uğratmaktadır. Bu durum ayııca turizmden elde edilen gelir oranının yükselmesinin önünde önemli bir engel teşkil etmektedir.

Turizm denince akla ilk gelenlerden bir tanesi turist olmaktadır. Turizm etkinlik ve aktiviteleri turistlerin istek ve ihtiyaçlarına göre şekillendirilmektedir. Bir turistin sadece ekonomik gelir kaynağı olarak düşünülmemesi gerekmektedir. Turistler, söz konusu bölgeye ya da yöreye ekonomik kazanç sağlarken aynı zamanda da kültürel etkileşimin gerçekleşmesini sağlamakta, kültürler arasında bilgi alısverişinin yapılmasını sağlayıp insanları bu konuda mutlu ve heyecanlı hissettirmektedirler.

Turizmde turist davranışlarının önemli bir yere sahip olduğu düşünülmektedir. Çünkü turistler, turizmi ayakta tutan önemli unsurlardan bir tanesidir. Turist davranışlarının kişisel değerler kapsamında irdelenmesiyle beraber turistlerin istek ve gereksinimlerinin daha iyi bir şekilde yerine getirileceği düşünülmektedir.

Turizm paydaşlarının turist odaklı karar alma süreçlerinde titiz bir şekilde davranması, turist davranışları konusuna olabildiğince önem verip özen göstermesi ve bu kapsamda çeşitli çalışmalar yürütmesi önemlidir. Bu kapsamda turizm paydaşları aracılığıyla turist davranışları ekseninde çeşitli görüşlerin bir araya getirilmesi gerekmektedir. Bir araya getirilen görüşlerin uygun bir şekilde değerlendirilmesiyle birlikte etkili ve verimli projeler gerçekleşeceği, bu projelerin de turist memnuniyetinin ve sadakatinin oluşmasında / artırılmasında etkili olacağı düşünülmektedir.

Kişinin tüketim kalıpları üzerinde yaşam stili ve kişisel değerlerinin önemli bir etkisi olduğu bilinmektedir. Değerler, genel olarak kişinin sahip olduğu fikir, inanç ve unsurlar olarak tanımlanmaktadır. Kişisel değerler kişinin hayatı süresince davranışlarına yön vermekte, rehberlik etmektedir. Bu değişken bir taraftan gündelik hayatı yönlendirirken, öbür taraftan ise tüketim davranışlarını etkilemektedir (Çolakoğlu, Türk, Başar ve Gül, 2013; Erciş ve Türk, 2014, s. 76). Kişisel değerlerin meydana gelmesinde kültürün ve toplumsal normların önemli bir rolü bulunmaktadır. Kişi, değerlerini içerisinde yaşadığı topluluktan öğrenmektedir. Esasen her toplulukta ya da her kültürde aynı değerler vardır. Lakin bireyin psikolojik dünyası ve toplumsal çevresinin etkisiyle değerlerin yansıması farklı olmaktadır. Kişisel değerleri; güvenlik, saygınlık arama, sosyal konumunu muhafaza etme veya yükseltme, diğer kişilerle sıcak uyumlu ilişkiler oluşturma, yaşamdan haz alma, başarılı olma, topluluk tarafindan aranan, istenen birisi olma ve benzeri değişkenler meydana getirmektedir. Değerler bu yönüyle davranışın hem nedeni hem de sonucudur. Sonuçta; değerler tutum, davranış ve yargilara kılavuzluk eder ve etkiler (Ünal ve Erciş, 2006, s. 361). Sosyal iletişim konusunda kişisel değerlerin çok etkili olduğu düşünülmektedir. Kişisel değerlere aykırı olan, olumsuz davranış ve tutumlar insanları duygusal olarak yıpratmakta, bu durum da turizm hareketlerine katılımı olumsuz yönde etkilemektedir.

Turizmde oldukça önemli bir konuma sahip olan turistlerin davranışlarının, kişisel değerler çerçevesinde ele alınması, hem psikolojik hem de sosyolojik olarak birçok problemin altında yatan nedenleri saptamak açısından önem arz etmektedir. Turistler ve diğer kişiler arasında yaşanan iletişimlerin, sorunların ve çözümlerin kişisel değerler kapsamında değerlendirilmesiyle turizme ekonomik, turistik, kültürel ve sosyolojik açılardan olumlu katkılar sağlanacağı düşünülmektedir.

Turistler kendilerini değerli, mutlu ve huzurlu hissedebilecekleri, memnun kalabilecekleri, doğal yaşantısından ve kültürel değerlerinden haz duyabilecekleri yerlere turistik amaçlı ziyaret gerçekleştirmek istemektedirler. Turistlerin bu tür istek ve ihtiyaçlarının yerine getirilebilmesi ekonomik, turistik ve kültürel açılardan önemli olarak görülmekte, bu durum da turizmde turistlerin apayrı bir yerinin olduğunu gözler önüne sermektedir. Turistler için herhangi bir destinasyonun güvenli olması ve ulaşım olanaklarının çok ve rahat olması oldukça önemli olarak görülmektedir.

Bu araştırmada, turist davranışlarının Schwartz değerler sistemi kapsamında değerlendirilmesiyle konu çok yönlü bir perspektifle ele alınmakta ve araştırma turist davranışlarının anlaşılması hususunda önemli ifadeler barındırmaktadır. 


\section{Literatür İncelemesi}

\section{Kişisel Değerler}

Genel manasıyla değerler, sosyal açıdan birtakım davranış ve gayeleri diğerlerinden daha çok tercih edilebilir yapan ve sürekliliği olan inanışlar olmaktadır (Odabaşı ve Barış, 2007; Erciş ve Türk, 2014, s. 76). Kişinin değerlerini; topluluktaki yerini koruma, saygınlık ve güvenlik gibi değişkenler meydana getirmektedir. Değerler, topluluk tarafindan kabul edilen, paylaşımı yapılan, olumlu ve beklenen davranışların neler olduklarını anlatan ölçütler ve düşüncelerdir. Dolayısı ile değer kavramı, nesnelerin ve hadiselerin önemine dair düşüncenin meydana gelmesini sağlayan insani bir nitelik olarak ifade edilmektedir. Yani, kişisel değerlerin seçim gerçekleştirmede, satın alınan ürünlerde, hobilerde ve başka kişisel tercihlerde etkili olduğu ifade edilmektedir (Michael ve John, 1988, s. 361). Bu seçimler ve tercihler, kişinin içerisinde bulunduğu toplulukla yakından ilişkili olmaktadır. Bu kapsamda kişinin değerleri, hayatın bütün alanı hakkındaki davranışlarda olduğu gibi, kişinin yenilikçi davranışları üzerinde de etkilidir. $\mathrm{Bu}$ durum da değerlerin, duygusal seviyede tüketiciyi motive eden, devamlı ve kalıcı bir yapisını ortaya koymaktadır (De Her ve Van Vliet, 2001; Erciş ve Türk, 2014, s. 77). Bundan dolay1 da kişisel değerler, davranışların hem nedeni hem de sonucu olmaktadır (Kahle, 1985, s. 231).

Değerler ve kişilik kavramları birbiriyle ilişkili olmakla beraber, değerler kişilerin neleri yapmamaları gerektiğini, kişilik ise kişilerin neleri yapma eğiliminde olduklarını belirtmektedir. Değerler, dış çevreden daha fazla etkilenir iken, kişilik ise daha içseldir (Mehtap, 2016, s. 22-43). Doğuştan gelen kişilik özelliklerinin tam tersine kişisel değerler, kişilerin hayatlarında veya başka sosyal kuruluşların işleyişinde kılavuzluk eden unsurlar olarak tercih edilen eylemlerle ilgili olarak öğrenilmiş inançlar olmaktadır (Costa ve McCrae, 1992, s. 653-665; Schwartz, 1994, s. 19-45.).

Kişisel değerler, kişilerin hayatlarında önemli olanın neler olduklarını ortaya koymaktadır. Bu açıdan çok sayılda olup, birbirinden farkllık göstermekte ve aynı zamanda kişilerin değişim gösteren önem derecelerinde çok saylda değere sahip olabilirler (Bardi ve Schwartz, 2003, s. 1207-1220). Değerler hususunda öncü isimlerden olan Rokeach (1973, s. 5; Yıldırım, 2013, s. 7), kişisel değerleri, seçenek davranışlara göre belli bir davranışın bireysel ya da toplumsal olarak tercihinin devamlilığında benimsenen inanç olarak ifade etmektedir. Dolayısı ile bir inanç olarak görülen kişisel değerler, kişilerin eylemlerini yönlendiren kimliğinin önemli bir bölümünü meydana getirmektedir (Jamaludin, Sam, Sandal ve Adam, 2016, s. 1-11).

Schwartz değerler sistemi içerisinde kişisel değerler 2 ana boyutta ele alınmaktadır. Söz konusu boyutlar ise; "değişime açıklk-mubafazakârllk" ve "takdir ve sayg görme-kendini aşma" biçimindedir. Bu 2 ana boyuttaki değerler toplamda 10 gruba ayrilmaktadır (Schwartz ve Bilsky, 1994, s. 167). "Değişime açıklıkmuhafazakârllk" boyutu içerisinde; "kendini yönlendirme", "uyarllm", "bedonižm", "güvenlike", "uyumluluk" ve "geleneksellik" değerleri bulunmaktadır. "Takdir ve saygı görme-kendini aşma" boyutu içerisinde ise; "evrensellik", "yardımseverlik", "gų̈s” ve "başarn” değerleri bulunmaktadır (Schwartz ve Bilsky, 1994, s. 167; Ünal, Deniz ve Can, 2008, s. 214).

Tablo 1. Değer Boyutları ve Tanmlar

\section{Tanım}

Örnek Değerler

\begin{tabular}{|c|c|}
\hline $\begin{array}{l}\text { Güç: Sosyal statü, sayginlık, insanlar ve kaynaklar üzerine } \\
\text { hâkimiyet ya da kontrol kurmaktır. }\end{array}$ & \\
\hline Başarı: Sosyal standartlara göre gösterilen kişisel bir başarıdır. & Başarılı, etkili, hırslı, yetenekli \\
\hline $\begin{array}{l}\text { Hazcılık (Hedonizm): Zevk ve hayatı sevmeye ilişkin bir } \\
\text { değer olmaktadır. }\end{array}$ & Haz değerleri, kendini şımartan, hayattan zevk alan, neşeli \\
\hline $\begin{array}{l}\text { Uyarılım: Hayatta heyecan, değişim ve rekabet aramakla ilgili } \\
\text { olan bir değerdir. }\end{array}$ & $\mathrm{n}$ \\
\hline $\begin{array}{l}\text { Kendini yönlendirme: Bu değer seçimde, düşüncede ve } \\
\text { araştırmada, yani düşüncede ve eylemde bağımsızlığ1 } \\
\text { içrmektedir. }\end{array}$ & $\begin{array}{l}\text { Kendi hedeflerini seçen, meraklı, özgürlük, bağımsı, } \\
\text { yaratıcllık }\end{array}$ \\
\hline $\begin{array}{l}\text { Evrensellik: İnsanlığın ve doğanın refahını muhafaza etmeyi, } \\
\text { kabul etmeyi ve anlamayı ifade eden bir değer olmaktadır. }\end{array}$ & $\begin{array}{l}\text { Barış içinde bir dünya, güzel bir dünya, açık düşünceli, eşitlik, } \\
\text { çevreyi koruyan, sosyal adalet, doğayla bütünlük, erdem }\end{array}$ \\
\hline $\begin{array}{l}\text { Yardımseverlik: Kişisel ilişki kurulan bireylerin refahını } \\
\text { düşünmekle ilgili bir değerdir. }\end{array}$ & Affedici, yardımsever, dürüst, sadık, sorumluluk sahibi \\
\hline $\begin{array}{l}\text { Geleneksellik: Bireyin dini, kültürü ve geleneklerine saygısını } \\
\text { ortaya koyan bir değerdir. }\end{array}$ & $\begin{array}{l}\text { Alçak gönüllü, llımlı, dindar, geleneklere saygill, yaşamdaki } \\
\text { yerini kabul eden }\end{array}$ \\
\hline Uyumluluk: Başkalarına zarar veren sosyal beklentileri ve & Öz disiplin, itaatkâr, nezaket, büyüklerine sayg1 \\
\hline
\end{tabular}


normları ihlal eden arzu, etkinlik ve hisleri kontrol etmekle

ilgili olan değerdir.

Güvenlik: Bireyin toplulukla olan ilişkilerinde uyum ve Aile güvenliği, ulusal güvenlik, temiz, karşılıklı iyilik, sosyal güvenliği ihtiva eden bir değerdir. düzen

Kaynak: Ünal vd., 2008, s. 214-215

\section{Turist Davranışları}

Turist davranışı, tüketici davranışıyla sıklıkla karıştırılan bir kavram olmaktadır. Turist davranışı, turistin aylar önce kendisini tatile hazırlaması ve tatil dönüşünde geniş ve uzun bir anımsatma dönemine sahip olması özelliğiyle tüketici davranışından farklılık göstermektedir (Pearce, 2005, s. 12). Ayrıyeten turistin boş zamanı çoğunlukla etrafinda şekillenmektedir (Jafari, 2000, s. 590; Sünbül, 2018, s. 33).

Turist davranışı; turistlerin seyahatleri süresince karşılaştıklanı bireyler ve yaşanılan turistik tecrübelerde sergilenen davranışlar olmaktadır (Günlü, 2007, s. 169). Doğru anlaşılması turizm ürünlerinin tüketicilere en iyi biçimde sunulmasını sağlamaktadır (Demir ve Kozak, 2011; Sünbül, 2018, s. 33).

Turistlerin; gidilen bölgeye karşı, yerli halkla arasındaki ilişki durumuna göre, başka turistlere yönelik ve turizm çalışanlarıyla ilgili olarak tutumları, turizm hareketindeki davranışları üstünde önem arz etmektedir. Buna ilave olarak ise; yerli halkın, turizm çalışanlarının ve başka turistlerin, konuk edilen turistlere karşı tutumları da turizm hareketinde ortaya çıkan davranışlar üzerinde etkili olduğu ifade edilebilmektedir (Akova, 2006, s. 5; Saatc1 ve Avc1kurt, 2016, s. 2541; Karakaş ve Şengün, 2017, s. 186).

Pek çok farklı gruplar arasında ve çeşitli şekillerde gözlemlenen tutumlara örnek verilecek olduğunda, turistlerin gidilen varış yerindeki yerel halka karşı ilgisizlik, üzüntü, acıma, ataerkillik, sade bir hayat coşkusu ve kültürel izafiyet gibi tutumları dikkat çekmektedir. Ífade edilen tutumlardan yola çıkılarak, turizmden fayda ve gelişme elde etmek için turizme ve turistlere karşı olan olumsuz tutumların değiştirilmesi gerektiği düşünülmektedir. Kişilerin turizm hususunda eğitim ve bilinçlenme seviyeleri artış gösterdikçe, turizme ve turistlere olan tutumların da olumlu yönde değişmesi öngörülmektedir (Rızaoğlu, 2003, s. 117).

İnsan odaklı bir endüstri olması nedeniyle kültür, turizm içinde oldukça önemli bir etkiye sahip olmakta ve kültür kapsamındaki din, dil, 1rk, tutum, alışkanlık, gelenek, görenek, sosyal değer ve normlar turist davranışlarını yönlendirmektedir (Tayfun ve Yıldırım, 2010, s. 48).

Turistler seyahat davranışlarını gerçekleştirirlerken, varış yerlerinin çevresel, tarihi, kültürel ve benzeri hizmetlerinin olmasına dikkat etmekle beraber seyahat kararlarında bu özelliklerden etkilenmektedirler (Akyurt ve Atay, 2009, s. 1).

Tablo 2. Kişilike Özellikleri ve Tatil Davranışı Arasında İlişkiler

\begin{tabular}{|c|c|}
\hline Kişilik / Seyahat Tipi & Kişilik Özellikleri \\
\hline Tatil seyahatçileri & Aksettirici, emin, etkin, girgin, meraklı, sempatik \\
\hline Tatil dışı seyahat edenler & Aksettirici, ciddi, çekingen, edilgen \\
\hline Otomobille seyahat edenler & Aksettirici, emin, etkin, girgin, meraklı, sempatik \\
\hline Havayoluyla seyahat edenler & Ayrıntılı düşünen, çok dikkatli, çok emin, çok etkin \\
\hline Trenle seyahat edenler & Aksettirici, bağımlı, edilgen, endişeli, kararsız, mesafeli \\
\hline Otobüsle seyahat edenler & Bağıml, çekingen, endişeli, hissi, kavgac1, kinci \\
\hline Ülke içi turistler & Dikkatli, etkin, sempatik \\
\hline Ülke diş1 turistler & Aksettirici, cesur, emin, macerac1, tepkisel \\
\hline Erkek turistler & Aksettirici, cesur \\
\hline Kadin turistler & Cesur, dikkatli, tepkisel \\
\hline Akraba ya da arkadaş ziyaretçileri & Edilgen \\
\hline Gözde varış yeri ziyaretçileri & Detaylı ve dikkatli düşünen, etkin, girgin \\
\hline Gezmek - görmek isteyenler & Aksettirici, çekingen, duygusal, edilgen, hissi, kararsız \\
\hline Açık hava faaliyetlerine katılanlar & Cesur, endişeli, etkin, girgin, istekli \\
\hline Kış tatilcileri & Etkin \\
\hline İlkbahar tatilcileri & Edilgen \\
\hline Yaz tatilcileri & Duygusal olarak kararlı, edilgen \\
\hline
\end{tabular}

Kaynak: Rizaoğlu, 2003, s. 87; Akçin, 2019, s. 85

Turizm hareketlerine katılan insan, içerisinde yaşadığı ve büyüdüğü çevreden çok, farklı çevreye giden ve yeni çevreye uymak mecburiyetinde olan bir kimsedir. Turistlerin gitmiş oldukları yerdeki davranışları ile doyumunda, içerisinde yetiştiği şartların ve gideceği yer hususundaki bilgilerinin önemli bir etkisi 
olmaktadır (Doğan, 2004, s. 18). İnsan, gittiği ortamda bir yabancıdır. Fakat bu yabancillğını ya gittiği çevreye uyum sağlayarak ya da yabancıllğını görmezden gelerek baskılayabilmektedir (Polat, 2013, s. 15).

Lanquar'ın (1985) ifadesine göre turizm, davranış değişikliklerine neden olmaktadır. Turizmin sosyal değerlerine dayalı bir yaklaşım; taklidi etmenler, din, fikir şekli, sosyal çevre, fikri ve kültürel formasyon, yaşa ve milliyete göre belirginleşen insan gruplarının turistik davranış ölçütlerine kaynak oluşturmaktadır. Bu gruplara göre bazı değerler değişmektedir. Bu değerler şöyledir (Lanquar, 1985, s. 44-45);

- Hayattan faydalanmak ve gereksinimleri tatmin etmek gerekir ve tatiller lüks olmaktan çıkarak bir ihtiyaç haline gelmektedir.

- Şehir yerleşiminin sebep olduğu huzursuzluktan ötürü hayata ve doğaya karşı duyarlı olmak gerekir.

- Bir sağlık problemi ve psikolojik denge, ilk olarak bir kayg1 şeklinde ortaya çıkmakta ve vücut ile zihin arasındaki uyumu sağlamaya destek olmaktadır.

- Para biriktirme eğilimi azalmaktadır.

- Aynı toplumsal paradokslarla karşı karşıya kalan kişiler değişmeyi ve kreatif olmayı git gide daha çok arzu etmektedir.

- Gittikçe artan oranda kişiler farklı duyumsal heyecanlara karşı daha çok duyarlı bir hale gelmektedir.

Turistler haz duygularını yaşarken, bulunulan ortamlara katkılar sağlamaktadır. İnsanların kişsisel değerler doğrultusunda mutlu bir hayat sürmesi, hayatından zevk alması, etrafına mutluluklar saçabilmesi turizm açısından önemli olarak görülmekte ve turizme pek çok açıdan da katkı sağlayacağ1 düşünülmektedir.

Doğal, kültürel ve turistik kaynakların varlı̆̆ı, her zaman turizm için önemli avantajlar sağlamaktadır. Farklı kültürlerden ve yörelerden gelen turistlerin Türkiye'yi ziyaret etmeleri turizm açısından çok sevindirici bir haber olarak insanların karşısına çıkmaktadır.

\section{Yöntem}

\section{Araştırmanın Amacı ve Önemi}

Turistlerin düşünce ve duygu dünyasının anlaşılmaya çalışılmaması, bazı kişilerin turistleri sadece gelir kaynağı olarak görmesi, yani, maddi açıdan önemseyip manevi açıdan önemsememesi, turist davranışının kişisel değerler odaklı olarak pek düşünülmemesi ve bu durumdan dolayı da turistlerin kişisel açıdan pek fazla memnun ve tatmin edilememesi, bu araştırmanın sorununu ortaya koymaktadır.

Turizmde önemli olan konulardan birisi, turist davranışlarının etkili bir şekilde anlaşılması ve bu şekilde turistlerin düşünce-duygu dünyasında yaşadıklarının farkına varılması olmaktadır. Turistlerin iç dünyasındaki düşünce ve duyguların açıklığa kavuşturulması, davranışlarının anlaşlabilmesi noktasında araştırma genelinde turistlerin davranışlarının neler olduğu ve kişisel değerler çerçevesinde nasıl değerlendirildiği sorusuna yanıt aranmaktadır.

Turistlerin hangi davranışlarının, hangi kişisel değerler kapsamına girdiği konusunda literatürde net bir bilgi bulunmamaktadır. Kişisel değerler, turizmde önemli bir potansiyele sahip olmakta fakat turist davranışları ile kişisel değerler üzerine gerçekleştirilen çalışmalara pek rastlanılmamaktadır. Turist davranışları ve kişisel değerlere dair yapılan çalışmaların sosyolojik, turistik, kültürel gibi birçok açıdan turizme önemli bilgi birikimleri kazandıracağı ve turist davranışlarını incelemede türlü yönlerden katkı sağlayacağı tahmin edilmektedir.

Günümüzde turizmden daha çok ekonomik bir gelir elde edilmesi için turist davranışlarının belirlenmesine yönelik çalışmalara ağırlık verilmesi gerektiği düşünülmektedir. Turist davranışlarına yönelik çalışmaların zenginleştirilmesi; bölge ve destinasyon imajını güçlendirecek, turizm markasının tanıtılmasında olumlu gelişmeler sağlayacak, turistlerin memnuniyet ve sadakatinin oluşmasında kayda değer katkılar sağlayacak, kültürel etkileşim ortamının yaşanmasına vesile olacak ve böylece turizmden elde edilen gelirin artmasını sağlayacaktır. Turist davranışlarının kişisel değerler odaklı ele alınması, literatürdeki eksikliğin giderilmesi açısından önemli olarak görülüp, bu çerçevede yeni ve güzel fikirler belirtmek oldukça önem arz etmektedir. Söz konusu çalışma bu duruma istinaden başlatılmış olup, bu doğrultuda şekillendirilmeye uygun görülmüştür. Herhangi bir yörede ya da destinasyonda bulunan bazı insanlar 
turistleri yalnızca para kaynağı olarak görürseler eğer; turistler bu durumdan olumsuz etkilenecektir. Turistler ziyaret ettikleri alanlara ekonomik, kültürel, psikolojik, sosyolojik ve benzeri açlardan katk1 sağlamaktadır. Bu durumun hiçbir kimse (özellikle turizm paydaşları) tarafından göz ardı edilmemesi gerekmektedir.

$\mathrm{Bu}$ araştırmanın amacı; Schwartz değerler sistemi çerçevesinde turist davranışlarını incelemektir. Bu inceleme işlemi gerçekleştirilirken de İstanbul ön plana çıkarılmaktadır. Turist davranışlarının ele alınmasıyla birlikte, turist davranışlarının sonuçları, turizm hareketlerini olumlu / olumsuz olarak nasıl etkileyebileceği vb. gibi durumlar ifade edilmeye çalışılmaktadır. Araştırma sonucunda ortaya çıkacak olan bilgiler sayesinde, tüm turizm paydaşlarına (özellikle turistlere ve turizm personeline) olumlu katkılar sağlanacağı ifade edilmektedir. Turizm sektöründe çok önemli bir konumda bulunan turistlerle iletişim konusunda oldukça dikkat edilmesi önem arz etmekte olup, bu hususta da gerekli tedbirlerin alınması gerektĭgi özenle vurgulanmaktadır.

Turist memnuniyetinin daha fazla elde edilmesi açısından turist davranışlarının kişisel değerler çerçevesinde saptanması önemli olarak görülmektedir. Kişisel değerlerin, turist davranışlarında çok etkili olduğu, bu alana dikkat çekmenin farklı bir izlenim (olumlu olarak) oluşturacağı ve farkındalık yaratacağ1 ifade edilmektedir. Bu araştırma, turistlerin davranışlarının kişisel değerler odaklı olarak hem sosyolojik, hem kültürel, hem de turistik açılardan değerlendirilerek turist davranışlarının farklı yönlerden anlaşılmasına olanak sağlamaktadır. Araştırmanın, turist davranışlarının değerlendirilmesi noktasında (özellikle sosyolojik, kültürel, turistik açılardan) önemli kolaylıklar sağlayacağı tahmin edilmektedir. Turizm personeli, turistlerin bazı davranış ve tutumlarına dair çeşitli bilgileri kısa zaman içerisinde kavrayabilir. Kişisel değerlerin bir insanın hayatında önemli yerinin olduğu düşünülmektedir. Araştırmanın, turistlerin istek ve gereksinimlerinin daha etkili bir şekilde karşlanıp turistlerin memnuniyet ve sadakatinin oluşmasına / artmasına katk1 sağlayacağı düşünülmektedir. Araştırma, ilgili konularda bundan sonra gerçekleştirilecek çalışmalar için bir bilgi kaynağı görevini üstlenmekte olup, kişisel değer ya da turizm konularındaki yeni çalışmaların şekillendirilmesinde çok önemli katkılarının olacağı ifade edilmektedir. Araştırmanın metodu; nitel araştırma metodu, araştırmanın veri toplama aracı; doküman analizi tekniği, veri analiz tekniği ise; betimsel analiz tekniğidir.

\section{Evren - Örneklem}

Araştırmanın evreni; İstanbul'dur. Bu evrenin tercih edilmesinin sebebi, turist yoğunluğunun fazla olmasından dolayıdır. Bu şehri, genel olarak yerli ve yabancı turistlerin yüksek oranda ziyaret ettikleri bilinmektedir. Araştırmanın örneklemi ise; İstanbul'daki turistlerin davranışları odaklı olarak oluşturulmuştur. Araştırmanın evreni İstanbul olduğu için, araştırma kapsamında toplanan verilerde de İstanbul ön plana çıkarılmaktadır. Bu kapsamda da söz konusu araştırmaya nitelikli bir biçim kazandırmaya gayret gösterilmiştir.

\section{Veri Toplama Araçları}

Bu çalışmada veri toplama aracı olarak doküman analizi tekniği kullanılmıştır. Doküman analizi, basıll-elektronik materyaller olmak üzere bütün dokümanları ele almak ve değerlendirmek amaciyla değerlendirilen sistemli bir metottur. Nitel araştırmada değerlendirilen başka metotlar gibi doküman analizi de mana çıkarmak, ilgili konuya dair bir anlayış meydana getirmek, ampirik bilgi geliştirmek amacıyla verilerin araştırılmasını ve yorumlanmasını gerektirmektedir (Corbin ve Strauss, 2008; Kıral, 2020, s. 173).

Araştırmanın verileri; makale, tez, internet kaynaklarından ve "İstanbul İl Kültür ve Turižm Bakanlğğ"nın yaptığı bir araştırmadan meydana gelmektedir. Araştırmanın verileri; 01.02.2021 - 06.02.2021 tarihleri arasında elde edilmiştir. Araştırma verileri elde edilirken şu tarz bir yol izlenmiştir: Google arama motoruna; "Istanbul turist", "İstanbul'daki turistlerin davranıslar", "İstanbul turizmi ve turist" ve "İstanbul bakkendaki turist yorumlan" teker teker yazilip incelenmiştir. Daha sonra da İstanbul'daki turistlerin davranışları üzerine internet üzerinden genel ve temel bir tarama yapılmıştır. Bu tarama yapılırken anahtar kelime vb. kullanılmayıp, konuya uygun olduğu düşünülen bilgilere ulaşmaya gayret gösterilmiştir. Veri toplama aşamasında ise literatürdeki bilgilerin, İstanbul'daki turistlere yönelik bilgilerin çoğunlukla istatistiki bilgi verme amaçlı olduğu görülmüsstür. Bu evrede, İstanbul'daki turistlerin davranışlarıyla ilgili bilgilere ulaşmada bir zorluk çekildiği ifade edilebilir.

\section{Verilerin Analizi}

$\mathrm{Bu}$ çalışmada veri analizi tekniği olarak betimsel analiz tekniği kullanılmıştır. Betimsel analizde görüşme ve gözlem yapma sonucu sağlanan verilerin düzenlenmiş ve yorumlanmış bir biçimde okuyucuya 
sunulması amaçlanmaktadır. Veriler daha önceden tespit edilmiş temalara göre sınıflandırılmakta, özetlenmekte ve yorumlanmaktadır. Bulgular arasında sebep-sonuç ilişkisi oluşturulmakta ve gerekirse olgular arasında kıyaslamalar yapılmaktadır (Yıldırım ve Şimşek, 2008, s. 224; Karataş, 2015, s. 73).

Schwartz değerler sistemi içerisinde kişisel değerler 2 ana boyutta ele alınmaktadır. Söz konusu boyutlar ise; "değişime ą̧ıkllk-muhafazakârllk" ve "takdir ve saygı görme-kendini așma" biçimindedir. Bu 2 ana boyuttaki değerler toplamda 10 gruba ayrilmaktadır (Schwartz ve Bilsky, 1994, s. 167): "Değişime açıklıkmuhafazakârllk" boyutu içerisinde; "kendini yönlendirme", "uyarllm", "bedonižm", "güvenlik", "uyumluluk" ve "geleneksellik" değerleri bulunmaktadır. "Takdir ve sayg görme-kendini assma" boyutu içerisinde ise; "evrensellik", "yardmseverlik", "güç" ve "başarn" değerleri bulunmaktadır.

$\mathrm{Bu}$ araştırmada turistlerin davranışları incelenirken Schwartz değerler sistemindeki toplamda 10 gruba ayrılan kişisel değerler göz önünde bulundurularak bir inceleme işlemi yapılmıştır. Araştırmada bulgular kısmında turist davranışlarıyla ilgili bilgiler doküman üzerinde ok işaretiyle gösterilmektedir. Ardından ise; ok işareti gösterilmeksizin bu turist davranışlarının hangi kişisel değerler ile ilgili olduğu ifade edilmektedir.

\section{Bulgular}

Araştırmanın bulguları kısmında, araştırma verileri ışığında toplamda 10 tema ortaya çıkmıştır. Bu temalarda genel olarak ise, turist davranışlarının Schwartz değerler sistemi içerisinde yer alan 10 kişisel değere ilişkin bir değerlendirme yapılmıştır. Bu kısımda, çoğunlukla doğrudan alıntılara yer verilerek araştırmanının kalitesi, etkililiği artırılmaya çalışılmıştır. Araştırma sonucunda ortaya çıkan temalar ve ilgili açıklamaları şöyledir;

Tema 1: Hedonizm-Kendini Yönlendirme-Evrensellik-Yardımseverlik-Geleneksellik Değerleri ile İlgili Turist Davranışları

Suudi Arabistanlı bir turist, tatil yapmak için en güzel seçeneğinin İstanbul olduğunu söylemektedir. Türkiye'yi Müslüman bir ülke olduğu için seçtiğini ifade eden turist, "turist olarak gittiğim bir ülkede ez̧an sesi duymak benim için önemli bir kriter. Türkiye'ye 2015 'te de geldim. İstanbul her gelisimde daha da gelisizyor. Alusveris imkânlar açsından çok güzel bir yer burası. Topkapı Sarayı'ndaki Kutsal Emanetler kasmma hayran kaldim. İstanbul hem bir Bat șehri hem de Doğu özelliklerini bünyesinde barndirryor. Ancak taksiciler bize firsat gözüyle bakiyor. Umarm bu durum da değgşir" ifadelerini kullanmıştır (Milliyet, 2017).

Bu durum; "bedonižm", "kendini yönlendirme”, "evrensellik", "yardimseverlik" ve "geleneksellik" kişisel değerleriyle ilgili olmaktadır. "Hedonižm" ile ilgili olarak; alı̧veriş imkânları açısından İstanbul'un güzel bir yer olduğu ifade edilmektedir. Alşsveriş eylemlerinin kişileri mutlu ettiği tahmin edilmektedir. "Kendini yönlendirme" ile ilgili olarak; Turistler ziyaret ettikleri yerle ilgili düşünce ve eylemlerini ifade etmektedir. "Evrensellik", ile ilgili olarak ise; taksicilerin turistleri bir firsat olarak görmesi erdemlik örnek değerine ters düşmektedir. Turistlerin kesinlikle hiçbir zaman bir firsat olarak görülmemesi gerekmektedir. "Yardımseverlik" ile ilgili olarak; taksicilerin turistleri bir firsat olarak görmesi dürüstlük örnek değerine ters düşmektedir. "Geleneksellike” ile ilgili olarak ise; ezan sesleri, Topkapı Sarayı'nda kutsal emanetler bölümü ve İstanbul'un batı şehri olup da Doğu'nun özelliklerini içermesi kişinin din, kültür ve gelenekleriyle ilgilidir.

İstanbul'u havası için tercih ettiklerini belirten Kuveytli bir turist, "Türkiye'ye ilk gelişimiz değil. Daba önce de ailemle iki kez geldik. İstanbul'u tercih ediyoruz cünkü taribi dokusu olduksca ilgi çekici. Elbette alssveris buradaki en cazip șey. Bunun dişinda yemekler de oldukça lezzetli" diyor. Kuveytli turist, İstanbul'da en çok rahatsız oldukları şeyi ise şu sözlerle anlatmaktadır: "baそ̌ insanlarn davranışlar

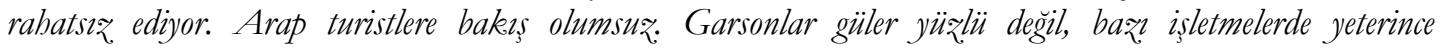
ilgilenilmiyor. Taksiciler ise fazla para istiyorlar" (Milliyet, 2017).

$\mathrm{Bu}$ durum; "bedonizm”, "kendini yönlendirme”, "evrensellik", "yardımseverlik" kişisel değerleriyle ilgili olmaktadır. "Hedonizm" ile ilgili olarak; İstanbul'un havasından ve yapılan alışverişin cazip olmasından dolayı zevk alındığı belirtilmektedir. "Kendini yönlendirme" ile ilgili olarak; İstanbul destinasyonun tercih edilmesi, İstanbul'daki lezzetlerin yenilmesi, bu destinasyonda bazı alısverişlerin yapılması kişinin yaptı̆̆ eylemde bağımsızlığını anlatmaktadır. "Evrensellik." ile ilgili olarak; İstanbul'daki birtakım insanların davranışlarının rahatsız edici olması, garsonların güler yüzlü davranmaması, birtakım işletmelerde yeterince ilgilenilmemesi, taksicilerin fazla para talep etmeleri evrensellik ilkesine ters düşmektedir. Bu kısımda ise sosyal adalet, erdem gibi örnek değerlere uyulmadığı göz çarpmaktadır. "Yardımseverlik" ile ilgili olarak; 
İstanbul'daki birtakım insanların davranışlarının rahatsız edici olması, garsonların güler yüzlü davranmaması, birtakım işletmelerde yeterince ilgilenilmemesi, taksicilerin fazla para talep etmeleri yardımseverlik ilkesine de ters düşmektedir. Bu kısımda ise dürüstlük ve sorumluluk sahibi olmak gibi örnek değerlere uyulmadığı göz çarpmaktadır.

Bahreynli turist ile ailesiyle geldiği İstanbul'daki son gününde konuşulmaktadır. Bahreynli turiste Türkiye'de hoşlarına gitmeyen şeyler sorulduğunda önce eşine bakmıştır. Ardından ise "gerçekten merak ediyor musun?" demiş ve anlatmaya başlamıştır: "alışveriş yaptık, güzel restoranlara gittik. Otelleriniz oldukesa modern. Şebir çok hoșumuza gitti. Ancak insanlarda bizimle ilgili olumsuz bir algz var.

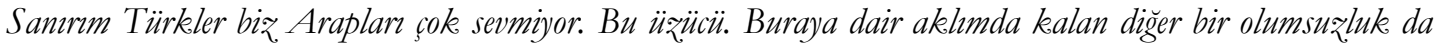
Suriyeliler" (Milliyet, 2017).

Bu durum; "bedonižm" ve "kendini yönlendirme" kişisel değerleriyle ilgili olmaktadır. "Hedonižm" ile ilgili olarak; şehrin turistlerin hoşuna gitmesi, otellerin modern olduğunun ifadesi (bu ifadeden mutlu olunduğu anlaşılabilir) haz değerlerine ilişkin olmaktadır. "Kendini yönlendirme" ile ilgili olarak; Türklerin Arap turistleri sevmediği düşünülmekte ve söz konusu durumda da Arap turistleri üzmektedir. Suriyelilerin Arap turistlerin akı1larında olumsuz olarak kalması da düşüncede bağımsızlı̆ı ifade etmektedir.

Koronavirüsle mücadele kapsamında alınan önlemlerden biri olan sokağa çıma kısıtlaması yabancı turistlere yaramıştır. Kısıtlamayla birlikte tenhalaşan İstanbul'daki turistler şehrin tadını çlkarmaktadır (Habertürk, 2020).

Bu durum; "bedonizm" ve "kendini yönlendirme" kişisel değerleriyle ilgili olmaktadır. "Hedonizm" ile ilgili olarak; turistlerin şehrin tadını çıkarması hazcılık ile ilgili olmaktadır. "Kendini yönlendirme" ile ilgili olarak; sokağa çıkma kıııtlamalarının turistleri kapsamadığı ve turistlerin bağımsız fikir ve eylemleriyle İstanbul ilinin tadını çıkardığı görülmektedir.

Bir turist, Moskova'da yaşamını sürdürdügünü, çok arzu etmesine karşın seferlerin durdurulması sebebiyle Türkiye'ye gelemediğini ifade etmiştir. Seferlerin yeniden başlamasıyla zaman kaybetmeden uçak bileti aldığını, arkadaşı ile İstanbul ilinde 12 gün kalarak gezeceklerini belirten turist, "İstanbul'u gezdikten sonra Kapadokya'ya geçeceğiz: Umarm Türkiye tatilimiz istediğimiz gibi geçer. İstanbul'da olduğumuz için çok mutluyuz” demiştir (TRT HABER, 2020).

Bu durum; "bedonizm" ve "kendini yönlendirme" kişisel değerleriyle ilgili olmaktadır. "Hedonizm” ile ilgili olarak; İstanbul'da olmaktan dolayı mutlu olan turist bulunmaktadır. "Kendini yönlendirme" ile ilgili olarak; turist, bağımsız düşünceleriyle önce İstanbul'u daha sonra ise Kapadokya'yı gezecekleri yönünde kendini yönlendirmektedir.

Dolmabahçe Sarayı ve Topkapı Sarayı'nı serbest bir şekilde gezebilen turistlerin Sultanahmet'te restoranların kapalı alanlarında bile yemek yiyebildiğini aktaran NYT, Amerikalı erkek arkadaşıyla buluşmak için İstanbul şehrine gelen 32 yaşındaki Britanyalı müzisyen bir turistin şu sözlerine yer vermiştir: "bu günlerde seyahat ettiğiniz için neredeyse cezalandirlmanz, bekleniyor ama burada dünyanm en güzel ve en büyüleyici kentlerinden birine erişebiliyoruz:" Turist, seyahat sonrası karantina uygulanmayan ve doğrudan uçuş olan az sayıda şehirden bir tanesi olduğu için İstanbul şehrini seçtiklerini ifade etmiştir (SÖZCÜ, 2020).

Bu durum; "bedonizm", "kendini yönlendirme" ve "geleneksellik" kişisel değerleriyle ilgili olmaktadır. "Hedonizm" ile ilgili olarak; İstanbul'dan dünyanın en güzel ve büyüleyici kentlerden birisi olarak bahsedilmektedir. İstanbul'un estetiksel güzelliği turistleri mutlu etmektedir. "Kendini yönlendirme" ile ilgili olarak; turistlerin kendi düşünceleriyle kendilerini yönlendirdikleri görülmektedir. "Geleneksellik" ile ilgili olarak; dünyanın en güzel ve büyüleyici şehirlerinden birisi olduğu ifade edilen İstanbul'un, kültür ve tarihinin de turistlerin bu fikirlerinin oluşmasında etkili olduğu düşünülmektedir.

İstanbul'a bakıldığında aslında kültür turizmi yönünden, gastronomi yönünden, güzergâhlar yönünden, sağllk yönünden, spor yönünden, sporun farklı çeşitleri yönünden, kültür - kongre turizmi yönünden, hangi alandan bakılırsa bakılsın meraklı, ögrrenmek isteyen, istifade etmek isteyen, görmek isteyen, neredeyse her turistin ilgisini cezbedebilecek bir şehirdir. Turizme ilişkin her alanda sözü olan, deneyime sahip olan bir şehirdir (T.C. İstanbul Valiliği, 2019).

Bu durum; "bedonižm", "kendini yönlendirme" ve "geleneksellik" kişisel değerleriyle ilgili olmaktadır. "Hedonizm" ile ilgili olarak; turizm, gastronomi, sağlık gibi yönlerden İstanbul turistlerin ilgisini üzerine çekebilecek bir şehir olmaktadır. Söz konusu yönlerin, turistlerin hayattan zevk alması ve mutlu olması 
üzerinde bir etkiye sahip olduğu tahmin edilmektedir. "Kendini yönlendirme" ile ilgili olarak; İstanbul, meraklı olan, öğrenmeyi arzu eden, istifade etmeyi düşünen, görmek isteyen kısacası ise kendi hedeflerini seçen, kendilerini yönlendirmek isteyen turistlerin ilgisini çekecek potansiyele sahip bir ildir. "Geleneksellike" ile ilgili olarak; İstanbul'un, turizm, kültür, gastronomi yönünden çoğu turistin ilgisini çekecek bir güce sahip olduğu ifade edilmektedir. Gastronomi ve turizm kapsamında düzenlenen çalışaların gelenekselliği, kültürü yansıttığı düşünülmektedir. Geleneksellik kişisel değerinin içerisinde turizm, gastronomi ve kültürün önemli bir yere sahip olduğu belirtilebilir.

Yedi tepe üzerine kurulmuş Tarihi Yarımada'nın merdivenleri şehre ayrı bir güzellik katar. Yapıldığı dönemin estetiğini yansıtan bu yapılar şehre gelen turistler için uğrak bir noktadır. En bilinenleri ise Bankalar Caddesi'ni Karaköy'e bağlayan Kamondo Merdivenleri, Çırağan Caddesi’ni Yıldız’a bağlayan Peri Çıkmazı ve Bebek semtinde Cevdet Paşa Caddesi ile Özlemli Sokağı'nı bağlayan 224 basamaklı Ehram Yokuşu'dur (Tüm Dünyanın Hayran Olduğu Şehir İstanbul Hakkında 8 İlginç Bilgi, 2020).

Bu durum; "hedonižm", "kendini yönlendirme" ve "geleneksellik" kişisel değerleriyle ilgili olmaktadır. "Hedonizm" ile ilgili olarak; yapıldığı dönemlerin estetik güzelliğini aksettiren İstanbul'daki bazı yapılar turistlerin ilgi odağı durumunda olmaktadır. Bu yapıların da özellikle estetik açılardan turistlere güzel bir duygu hissettirdiği ve onları mutlu ettiği düşünülmektedir. "Kendini yönlendirme" ile ilgili olarak; turistlerin İstanbul'daki söz konusu yapıları bağımsız fikirleri ve eylemlerinden yola çıkarak ziyaret ettikleri tahmin edilmektedir. Turistlerin bu fikir ve eylemleri üzerinde ise kültürel ve turistik unsurların etkili olduğu belirtilebilir. "Geleneksellik" ile ilgili olarak; İstanbul'da Tarihi Yarımada'da yer alan merdivenlerin, İstanbul'a önemli bir güzellik kattığı ifade edilmektedir. Bu yapılar, yapıldığı dönemin estetiğini yansıtmakta, yapıldığı zamanın gelenekselliğinden ve kültüründen izler taşımaktadır.

Türkiye'nin en kalabalık kenti olan İstanbul, dünyanın da en kalabalık 10 kenti arasında bulunmakta ve Türkiye'nin de en büyük kenti olmasının yanında hem doğal güzelliği hem de tarihsel dokularıla yerli-yabancı turistlerin ilgisini fazlasıyla çekmektedir (Opan, 2019).

Bu durum; "geleneksellik" kişisel değeriyle ilgili olmaktadır. "Geleneksellik." ile ilgili olarak; İstanbul'un doğal güzelliği ve tarihi dokularıyla yerli ve yabancı turistleri etkilediği ifade edilmektedir. Geleneksellik değerine göre; doğal güzellik ve tarihi doku önemlidir.

UNESCO Kültür Mirası Listesi’ne giren ilk kültürel varlıklarımız İstanbul ilinde bulunan ve Tarihi Yarımada olarak isimlendirilen "Sultanabmet Kentsel Arkeolojiz Sit Alanı", "Süleymaniye Koruma Alanı", "Zeyrek Koruma Alanı" ve "İstanbul Kara Sular Koruma Alanı" olmuştur. Birden fazla uygarllğın, imparatorluğun, kültürün uğradığı dünya başkentleri arasında bulunan İstanbul ili, bu yönü ile aslında bir müze konumunda olmaktadır. İstanbul ilinde görülmesi gereken yerlerin ilk sıralarında gelen bu rotalar, yerli-yabanc1 turistlerin ilgisini cezbederken, bütün görkemiyle de göz doldurmaktadır (JOLLY, 2018).

Bu durum; "geleneksellik" kişisel değeriyle ilgili olmaktadır. "Geleneksellik" ile ilgili olarak; kültürel ve tarihsel açıdan çok öneme sahip olan İstanbul, bu yönüyle yerli ve yabancı turistlerin ilgisini çekmektedir. Turistlerin asıl amacının ise, İstanbul'un kültürel ve tarihi değerlerini yakından tanımak olduğu tahmin edilmektedir.

İstanbul'u İstanbul yapan simgelerin başında Topkapı Sarayı gelmektedir. Tarihi Yarımada'nın merkezinde bulunan ve Osmanlı İmparatorluğu'nun 600 senelik tarihinin 400 senesi süresince, idare merkezi olarak değerlendirilen ve Osmanlı padişahlarının hayatını devam ettirdiği saray olan Topkapı Sarayı, bugün de bütün ihtişamılla İstanbul ilinin kalbinde olmayı başarmaktadır. Dünyadaki en köklü tarihi yapilardan bir tanesi konumunda olan ve 1478 senesinde Fatih Sultan Mehmet tarafindan yaptırlan Topkapı Sarayı, hâlihazırda müze olarak değerlendirilmeye devam etmektedir. Dünyanın en zengin müzelerinden birisi olan Topkapı Saray1, hafta sonu veya hafta içi fark etmeksizin turistlerin yoğun ilgisini görmektedir. Yerli turistlerin de en fazla ziyaret gerçekleştirdiği müzelerin başında bulunan Topkapı Sarayı Müzesi hırka-i saadet dairesi, kutsal emanetler, imparatorluk hazinesi, Avrupa porselenleri, padişah kaftanları, gümüşler ve portre koleksiyonları gibi farklı koleksiyondan eserler içermektedir. UNESCO Dünya Mirasları Listesi'nde bulunan Topkap1 Sarayı'nda dört avlu ve harem dairesi yer almaktadır. Enderun Avlusu tarafinda yer alan Osmanlı devrine ait nadide minyatür ve hat sanatlanı ile kaşıkçı elması ise en fazla ilgi çeken eserler arasında bulunmaktadır (JOLLY, 2018). 
Bu durum; "geleneksellik" kişisel değeriyle ilgili olmaktadır. "Geleneksellik" ile ilgili olarak; Topkap1 Sarayı'nda yer alan pek çok tarihi, turistik ve kültürel niteliğe sahip olan değerler turistler için önemli olarak görülmektedir. Turistler, bu söz konusu değerleri görmek ve yakından tanımak için Topkapı Sarayı'nı ziyaret etmektedir. Bu durum, geleneksellik kişisel değeri için önemlidir.

İstanbul - Sultanahmet’te turistlerin şikâyet ettiği dört problem olmaktadır. Başlıca olan bu problemler: dilenciler, hanutçular, parfüm vs. satış yapan seyyar satıcılar ve taksicilerdir. Dilencilerin kişisel ya da örgütsel olarak turistlere inanılmaz seviyede rahatsızlık verdikleri görülmektedir. Bu durum zaman zaman kamuoyuna da yansımaktadır. Yerde yatıp duygu sömürüsü yapan, devamlı turistlerin peşinde koşan ve zorla para almaya uğraşan, çöp konteynerlerinin çevresinde 5-6 kişi toplanıp turistlerin dikkatlerini çekmeye çalışan dilenciler olmaktadır. Turistler de bu görüntüleri çekerek, sosyal mecralarda paylaşım yapmaktadırlar. Bu durum da, ister istemez ülke imajına zarar vermektedir. Hanutçuluk, bilhassa turizmin yoğun olduğu bölgelerde görülen bir durum olmaktadır. Hanutçuluk yapan insan, bilhassa turist kafilelerini alışveriş yapmaları amacıyla belirlenen mağazalara ve dükkânlara götürmekte ve belirli bir yüzde almaktadır. Kafilelerin götürüldükleri dükkânlar olabildiğince iyi kazanç sağlarken, yakınındaki esnaf ise bir iş yapamaz hale gelmektedir. Parfüm ve benzeri eşya satışlarını seyyar olarak gerçekleştiren insanlarla ilgili inanılmaz derece şikâyetler gelmektedir. Bu insanlar, turistlere karşı nezaket kurallarına aykıın davranışlar sergilemektedirler. Turistlerin istemedikleri bir ürünü zorla satmaya çalışmakta; bağırma, çağırma, korkutma metotlarına başvurmaktadırlar. $\mathrm{Bu}$ çeşit olaylar gün geçtikçe artmakta ve daha tehlikeli bir hal almaktadır. Bazı zamanlar sosyal ve ulusal medyada da şahit olunduğu üzere, nahoş olan olaylar gerçekleşmektedir. Gayesi yalnızca turisti avlamak olan birtakım taksicilerin olduğu bilinmektedir (Turizm Günlüğü, 2020).

Bu durum; doğrudan "evrensellik" ve "kendini yönlendirme" kişisel değerleriyle ilgili olmaktadır. Turistlerin refahının korunması ve anlaşılması gerekmektedir. Ama bu kısımda belirtilen bilgilere göre turistlere yapılan hareketler turistlerin memnuniyetsizliğine neden olmakta, "evrensellik" değerine de ters düşmektedir. Turistlerin dikkatlerini çekmeye uğraşan dilencilere karşı turistler de bu halin görüntülerini çekip, sosyal mecralarda paylaşım yapmaktadırlar. Turistlerin gerçekleştirdikleri bu tür davranışlar da kişisel değerlerden olan "kendini yönlendirme" değeriyle ilgilidir.

Tema 2: Güç-Kendini Yönlendirme-Yardımseverlik-Uyumluluk-Güvenlik Değerleri ile İlgili Turist Davranışları

ABD'den eşi ve çocuğuyla İstanbul iline gelen bir turist, "kesinlikle Türkiye'de kendimi güvende bissediyorum" deyip Türk insanının hijyen hususunda aşırı derecede hassas olduğunu vurgulamıştır. Turist, Türkiye'deki gözlemlerini şöyle özetlemiştir: "Türkler corona virüsü̈ önemsedi ve ciddi önlemler ald. Özellikle burada insanlarn hepsi eldiven ve maske takiyor. Kolonya ve dezenfektan kullanyyor. Cemaatle namazlar bile yasaklandı. Böyle durumlarda yapılmast gereken doğru bir sey. 2 gün sonra Türkiye'den ayrlacağım. Buranm güvenli olduğunu düs̈̈̈ndügüm için ailem konusunda çok tedirgin değ̈ilim" (NTV, 2020).

Bu durum; "güc", "kendini yönlendirme", "yardmseverlik", "yyumluluk," "güvenlike" kişisel değerleriyle ilgili olmaktadır. "Gǚs" ile ilgili olarak; Türkiye'nin Koronavirüs'ü önemsemesi ve ciddi önlemler alması, özellikle İstanbul'da insanların hepsinin eldiven ve maske takması, kolonya ve dezenfektan kullanması güç ile ilgilidir. Bilhassa da sosyal güç, otorite örnek değerleriyle ilgili olmaktadır. "Kendini yönlendirme" ile ilgili olarak; turist bağımsız düşüncesiyle İstanbul'a gelmiştir. Türkiye'nin güvenli bir ülke olarak da hissedilmesi, turistin bu kararı almasında etkili olduğu tahmin edilmektedir. "Yardmmseverlike" ile ilgili olarak; Türklerin Koronavirüse karşı önlem alma konusunda sorumluluk sahibi olduğu ve çevresine güven aşıladığ1 görülmektedir. "Uyumluluk" ile ilgili olarak; insanların hayatlarını tehdit eden Koronavirüsün yayılmasını engellenmek amaciyla birtakım kurallar (eldiven ve maske takma, cemaatle beraber namaz kılınmasının yasaklanması gibi) uygulanmaktadır. İnsanların da bu kurallara uydukları görülmektedir. "Güvenlik" ile ilgili olarak; Türkiye'nin güvenli bir yer olduğu ifade edilmektedir. Türklerin Koronavirüs konusunda önemli önlemler alması, can güvenliğinin sağlanması ve sosyal düzenin bozulmaması içindir.

İstanbul iline Kırgızistan'dan gelen bir turist virüslere karşı senelerdir sağlıklı beslenme ile mücadele ettiğini ifade ederek, "İstanbul'a ilk defa geldim. Ku乏̌enlerim burada yaşıyor. Burada kendimi güvende hissediyorum. Ayrca kendi sağh̆ğma da dikkat ettiğim için tedirgin değilim" ifadelerini kullanmıştır. Tek üzüntüsünün müzeleri ziyaret edememek olduğunu belirten turist, "ama Istanbul'u yürïyerek, kessfediyorum" diyerek sözlerini tamamlamıştır (NTV, 2020). 
Bu durum; "kendini yönlendirme" ve "güvenlik" kişisel değerleriyle ilgili olmaktadır. "Kendini yönlendirme" ile ilgili olarak; bir turistin İstanbul'a ilk kez gelmesi ve bir turistin de İstanbul'u yürüyerek keşfetmesi, düşünce ve eylemde bağımsızlı̆̆ içermektedir. "Güvenlik" ile ilgili olarak; İstanbul içinde güvende hissedilmektedir.

Tema 3: Hedonizm-Kendini Yönlendirme-Geleneksellik-Uyumluluk-Güvenlik Değerleri ile İlgili Turist Davranışları

Rusya'dan kafile ile Türkiye'yi ziyarete gelen turistlerden bir tanesi Türkiye'yi çok sevdiğini ifade ederek, "Koronavirüs ya da başka bir șey bizi buraya gelmekten engelleyemez: Burada hem güneș hem tarih var. Türkleri cok seviyoruz. Hiçbir sey bizi korkutamaz: Bi‡. Türklerle kardesiz. 10 gün daha buradaynz" demiştir. Aynı grupta olan başka bir turist de "Türkiye güvenilir bir ülke ve burada olmaktan mutluluk duyuyoru: Her zaman geldik ve gelmeye devam edeceğiz. Sultanabmet bölgesini gezmeye baynlyorum. Her defasinda farkh seyler kesfediyorum. Bu defa biraz sakin ama bunun da güzel taraflar var" ifadelerini kullanmışır (NTV, 2020).

Bu durum; "bedonizm", "kendini yönlendirme", "geleneksellik", "uyumluluk", "güvenlik" kişisel değerleriyle ilgili olmaktadır. "Hedonizm” ile ilgili olarak; Türk insanlarının sevilmesi, Türkiye'de olunmasından mutluluk duyulması, Sultanahmet bölgesini gezmenin sevilmesi, güneşin tadının çıkarılmak istenmesi hazcllık ile ilgilidir. "Kendini yönlendirme" ile ilgili olarak; turistlerin kendi fikirleriyle Türkiye'yi ziyarete gelmesi, buraya gelmelerini Koronavirüs ya da başka şeylerin engellenemeyeceği ifadesi de kendini yönlendirmeyle ilgilidir. "Gelenelesellik" ile ilgili olarak; Türkiye'nin tarihine ve Sultanahmet bölgesine ilişkin ifadeler geleneksellik ile, özellikle de kültür ile ilgilidir. "Uyumluluk" ile ilgili olarak; Rusya'dan gelen turistlerden bir tanesinin kendilerini Türklerle kardeş olarak görmesinin, manevi açıdan bir uyumluluk hissetmesiyle ilgili olduğu düşünülmektedir. "Güvenlik," ile ilgili olarak ise; turistlerden bir tanesi tarafindan Türkiye'nin güvenilir bir ülke olduğu düşünülmektedir.

Tema 4: Hedonizm-Uyarılım-Kendini Yönlendirme-Geleneksellik Değerleri ile İlgili Turist Davranışları

Büyükada meydanında bir araya gelen kalabalı̆ı̆n arasına girilmiştir. Arapça atılan naralarla gelinlik ve damatlıkların içerisinde iki Iraklı çiftin eğlencesine denk gelinmiştir. Iraklı çiftler için İstanbul ilinde dügün son senelerin yükselen bir modası olmuştur. Çiftler konuşmak istemese de onlardan bir tanesinin amcası olan bir kişi anlatmaya başlamıştır: 'Trak'ta İstanbul'da dügün ve

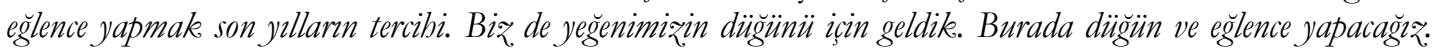
Boğaz ve adalar turunun ardindan ülkemize döneceğiz. Türkiye, çok büyük ve gelismis bir ülke. Burada olmak biri mutlu ediyor. Ancak daha fazla Arapsa tabela olsa bizler için iyi olacak. Araba kullanrken yol bulmak biraz, zor oluyor" (Borsa Gündem, 2017).

Bu durum; "hedonizm", "yyarllm", "kendini yönlendirme" ve "geleneksellik" kişisel değerleriyle ilgili olmaktadır. "Hedonizm" ile ilgili olarak; İstanbul'da düğun ve eğlence yapılması, Türkiye'de bulunulmasından dolayı mutlu olunması hazclikla ilgilidir. "Uyarnlım" ile ilgili olarak; Iraklı çiftlerin İstanbul'da düğün yapması, farklı bir heyecan, değişim yaşamak için ve İstanbul'da bu düğün yapma eyleminin moda olduğundan dolayıdır. "Kendini yönlendirme" ile ilgili olarak; turistler düğün yapmak, boğaz ve ada turu yapmak istemekte, söz konusu hal ise turistlerin fikir ve eylemlerinde bağımsızllğı içermektedir. “Geleneksellik”, ile ilgili olarak; turistlerin düğün ve eğlence yapması, kültür ve gelenekler ile ilgilidir.

Arap turistler için Büyükada illk sırada olmak üzere adalar, kentin en ilginç kısmı olmaktadır. Hafta sonu ilgi çok yüksek olsa da hafta içi de vapurlar yüzlerce Arap turisti Büyükada'ya taşımaktadır. Restoranlar, dondurmacılar ve elbet faytoncular da yavaş yavaş Arapça öğrenmiştir. Tabelalarda en az Türkçe kadar Arapça ifadeler bulmak mümkün olmaktadır. Bir turist ve ailesi Kuveytlidir. Bu Kuveytli turist, "faytonla adada tur atmak oldukesa ilginc bir deneyimdi. İstanbul oldukça güzel bir şebir" demiştir. Ürdünlü bir turist de Büyükada’ya geldiklerinde olabildiğince etkilendiğini ifade ederek, "cocuklarmla faytona binmek için geldik. Dondurmalar çok beğendik" demiştir (Milliyet, 2017).

Bu durum; "bedonizm", "kendini yönlendirme", "uyarnlm” kişisel değerleriyle ilgili olmaktadır. "Hedoniz̧m" ile ilgili olarak; İstanbul'un çok güzel bir şehir olduğunun ifade edilmesi ve dondurmaların çok beğenilmesi hazcllk ile ilgili görülmektedir. Kuveytli turistlerin İstanbul ile ilgili görüşlerini paylaşması ve eylemlerini ifade etmesi "kendini yönlendirme" ile ilgilidir. "Uyarllm" ile ilgili olarak; Kuveytli turistlerin Büyükada'da faytonla tur atması ve ilginç deneyim yaşaması ise uyarılım ile ilgilidir. 
Türkiye'nin iç turizmde turist gönderen önemli bir pazarı olan İstanbul'da, yerli turistler hediyelik eşya işletmelerinin orijinal, kaliteli ürünler satan, personel hizmet kalitesi yüksek, otantik ve hoş bir ambiyansa sahip, farklı ödeme imkânları sunan, temiz ve iyi bir aydınlatmaya sahip, kolay ulaşım imkânı sağlanabilen mağazalar şeklinde olmasını istemektedir. Yerli turistler tarafindan hediyelik eşya işletmelerinde bulunan hediyelik ürünlerin; bakımı kolay ve temiz, kaliteli işçiliğe sahip, çekici renk ve tasarımı olan, kullanılabilirliği yüksek ve bölgenin yerel kaynakları kullanılarak yapılması arzu edilmektedir. Buna ek olarak hediyelik eşyaların çeşitlendirilmesi beklenmekte, akabinde yapılacak olan hediyeliklerin zanaatkârlar tarafindan yapılması ve bölgeye özgü olması beklenmektedir (Y1lmaz, 2018, s. 87).

$\mathrm{Bu}$ durum; "hedonizm", "uyarllım" ve "kendini yönlendirme" kişisel değerleriyle ilgili olmaktadır. "Hedoniz̨m" ile ilgili olarak; yerli turistler, hediyelik eşya işletmelerinin ve hediyelik eşya ürünlerinin kendi zevklerine uygun özellik ve niteliklere sahip olmasını beklemektedir. Örneğin hediyelik eşya dükkânlarının otantik ve hoş bir ambiyansa sahip olması, hediyelik eşya ürünlerinin de çekici renk ve tasarıma sahip olması turistler için önemli olmakta, verilen bu örneklerde de hazcılık değerinin ön plana çıktı̆̆1 görülmektedir. "Uyarllım" ile ilgili olarak; yerli turistlerin hediyelik eşyaların farklılaştırılmasını beklemesi, sonrasında yapılacak olan hediyeliklerin zanaatkârlar aracıllğıyla yapılmasını ve bölgeye has olmasını beklemesi de kişisel değerlerden uyarılım değeri ile ilgili olmaktadır. "Kendini yönlendirme" ile ilgili olarak; yerli turistlerin hediyelik eşya ürünleri ve işletmelerine yönelik belli bir beklentileri söz konusu olmaktadır. Söz konusu beklentilerin de yerli turistlerin kendilerini yönlendirmelerinde etkili olduğu savunulabilir.

İstanbul özellikle son yllarda Türk ekonomisinin yükselen trendi, tarihi güzellikleri ile Türk dizilerinin de yabancı ülkelerdeki izlenme oranlarının yüksek olması sebebiyle, Ortadoğu, Balkanlar ve Doğu Bloku ülkeleri gezginleri tarafindan görülmesi öncelikli ş̧ehirler listesine girmiş ve düzenli olarak ziyaretçi sayısını artırmıştır. Türk Hava Yolları'nın (THY) son 10 yıldaki hızlı ve efektif büyümesi ile dünyanın en fazla destinasyonuna uçan 1. havayolu olması da, THY'nin hub olarak kullandığı İstanbul'un turist sayısını düzenli artırmıştır. Tabii burada Kültür ve Turizm Bakanlığı’nın ve hükümetlerin sektöre verdiği destek ve teşviklerini de unutmamak gerekmektedir. İstanbul'un aynı anda hem İslam hem Hristiyan hem de Musevi dininin izlerini taşıyan bir şehir olması da gizemini artırmakta, Boğaz'ın eşsiz güzelliği ve dünyanın hiçbir yerinde olmayan doğal yapısı ile misafirlerin hafızalarında unutulmayacak bir iz bırakmaktadır (STAR, 2015).

Bu durum; "kendini yönlendirme", "geleneksellik" ve "yyarllım" kişisel değerleriyle ilgili olmaktadır. "Kendini yönlendirme" ile ilgili olarak; tarihi güzelliklerin, Türk ekonomisinin yükselen bir trendinin olması ve Türk dizilerinin de yabancı ülkelerde seyredilme oranlarının yüksek olmasının etkileriyle birlikte İstanbul'a gelen ziyaretçi sayıları artış göstermiştir. Bu kapsamda, kendi hedeflerini belirleyen, merak sahibi, özgürlüğü seven, bağımsız turistlerin yani kendini yönlendirmek isteyen turistlerin İstanbul'a seyahat gerçekleştirdiği ifade edilebilir. "Geleneksellik" ile ilgili olarak; İstanbul'un İslamiyet, Hristiyanlık ve Musevilik dinlerinden önemli emareler taşıması, bu destinasyona ait olan turizm talebini artırma noktasında bir etkiye sahiptir. Turistlerin din, kültür ve geleneklerine saygı duyması ve bunları daima göz önünde bulundurması ile geleneksellik kişisel değeri bir paralellik göstermektedir. "Uyarllm”' ile ilgili olarak; İstanbul Boğazı, güzelliği ve dünyanın hiçbir yerinde bulunmayan bir doğal yapısıyla konukların zihinlerinde unutulmaz bir bırakmakta, bu durum da uyarılım kişisel değeriyle ilgili bir benzerlik taşımaktadır.

Kentin en uğrak noktalarından olan Ortaköy, yağmura aldırış etmeyen turistleri ağırlamıştır. Gruplar halinde gezilerini sürdüren turistler, köprü manzarasında hatıra fotoğrafi çektirmiştir (Takvim, 2021).

Bu durum; "kendini yönlendirme" ve "geleneksellik" kişisel değerleriyle ilgili olmaktadır. "Kendini yönlendirme" ile ilgili olarak; turistler gezilerini gruplar halinde sürdürmekte ve bu şekilde kendilerini yönlendirmektedirler. "Geleneksellik" ile ilgili olarak; İstanbul-Ortaköy'de bulunan, tarih ve kültürden çeşitli izler taşıyan köprünün fotoğrafları turistler tarafindan çekilmiştir.

İspanya'dan gelen 53 yaşındaki bir turist şu şekilde konuşmuştur: "bayat, bir ynl daba evde kalmak için çok kisa. Cok uzun bir süre kafese kilitlenmis hayvanlar gibi hissettik ve kaçp fark.h kültüre sabip bir yeri görmek istedik" (Gazete Duvar, 2020).

Bu durum; "kendini yönlendirme" ve "geleneksellik" kişisel değerleriyle ilgili olmaktadır. "Kendini yönlendirme" ile ilgili olarak; evde kalmaktan dolayı sıkılan turistler farklı kültürlere sahip bir yeri görmek için 
gidecekleri yeri seçmişlerdir. Yani kendilerini yönlendirmişlerdir. "Geleneksellik”" ile ilgili olarak; turistler için farklı kültürleri tanımak önemlidir. Kültür, geleneksellik değerinin içerisinde yer alan bir öge olmaktadır.

İstanbul, Eminönü'nde, Yeni Camii'nin hemen arka kısmında yer alan Mısır Çarşısı, İstanbul ilinin en eski kapalı çarşılarından birisi olmaktadır. Mısır Çarşısı, içindeki yüzlerce çeşitli baharatlarıyla dikkat çekmektedir. Turistlerin yoğun bir ilgi gösterdiği Mısır Çarşııı'nda aktarlar, doğal karışımlar, bitki kökleri gibi çeşitli ürünler bulunmaktadır (JOLLY, 2018).

$\mathrm{Bu}$ durum; "kendini yönlendirme" ve "geleneksellik" kişisel değerleriyle ilgili olmaktadır. "Kendini yönlendirme" ile ilgili olarak; Mısır Çarşısı'nı ziyaret eden turistlerin amaçları (çoğunluk olarak) alışveriș gerçekleştirmektir. Turistler alışveriş gerçekleştirmekle ilgili düşüncelerinde ve eylemlerinde bağımsızdırlar. Alışveriş imkânları geniş yerler, turistler için önemlidir. "Geleneksellike" ile ilgili olarak; İstanbul ilinin en eski kapalı çarşılarından bir tanesi olan Mısır Çarşısı, ticaret ve kültür açısından önem arz etmektedir. Buradaki doğal karışımlar, bitki kökleri gibi farklı ürünler yöre/bölgelerden çeşitli izler taşımaktadır. Bu izlerin üzerinde de kültürün bir etkisi ve önemli bir payının olduğu düşünülmektedir. Kapalı çarşılar, kültür ve gelenek-görenekler ile ilgili yakından ilişkilidir.

Osmanlı devrinde "Cadde-i Kebir", yani Büyük Cadde olarak isimlendirilen İstiklal Caddesi, 19. asrın sonlarından bu yana Türkiye'nin en meşhur caddesi unvanını korumaktadır. 1.400 metre uzunluğa sahip İstiklal Caddesi'nin üstünde Galatasaray Lisesi, Çiçek Pasaj1 başta olmak üzere birden fazla tarihi pasaj, hanlar, tiyatrolar, kitap evleri, sanat merkezleri, çarşılar, dükkânlar ve kafeler bulunmaktadır. Başlangıç alanının Atatürk heykeli olduğu İstiklal Caddesi, tünel ve devaminda Galata'ya, oradan da Karaköy'e uzanan tarihi bir yürüyüş rotası meydana getirmektedir. Türkiye'yi ziyarete gelen yerli veya yabancı turistlerin ilk uğradığı yer olan İstiklal Caddesi'nin simgesi ise kırmız1 rengi ile nostaljik tramvay olmaktadır (JOLLY, 2018).

Bu durum; "kendini yönlendirme" ve "geleneksellik" kişisel değerleriyle ilgili olmaktadır. "Kendini yönlendirme" ile ilgili olarak; İstanbul'da yer alan İstiklal Caddesi'ni turistlerin daha çok turistik gezi amaçlı değerlendirdikleri tahmin edilmektedir. Turistlerin kendilerini yönlendirmelerinde ise bağımsız fikirleri, eylemleri, yeni kültür ve toplumları tanıma arzularının etkin olduğu tahmin edilmektedir. "Geleneksellik" ile ilgili olarak; Türkiye'ni en ünlü caddelerinden birisi olan İstiklal Caddesi, turistlerin ziyaret ettikleri alanlar arasında bulunmaktadır. İstiklal Caddesi üzerinde pek çok somut yapı yer almaktadır. Bu somut yapıların ise; kültürden, gelenek-görenekten, tarihten çeşitli izler taşıdığ ifade edilebilir. Turistler, bu somut yapıları gezmek, görmek ve tanımak istemektedir. Bu durum ise; geleneksellik kişisel değeriyle bir paralellik göstermektedir.

"Turižm açssndan dünyann en önemli șebirlerinden biri olan İstanbul; bilim, kültür ve sanatın merkę̧i olarak ber yul milyonlarca turisti ağgrlyyor" (T.C. İstanbul Valiliği, 2019).

$\mathrm{Bu}$ durum; "kendini yönlendirme" ve "geleneksellik" kişisel değerleriyle ilgili olmaktadır. "Kendini yönlendirme" ile ilgili olarak; İstanbul'un turistleri kendisine çektiği görülmektedir. Turistlerin destinasyon seçimi düşüncesinde ve eyleminde bağımsız olduğu ifade edilebilir. "Geleneksellik" ile ilgili olarak; İstanbul'un sanat ve kültür merkezi olarak görülmesi gelenekselliği yansıtan bir durumdur. Ülke, bölge veya yörelerin sanat ve kültürlerini tanımayı arzu eden turistlerin odak noktasında ise gelenekselliğin bulunduğu ve merak unsurunun ön planda olduğu düşünülmektedir.

Tema 5: Uyarılım-Geleneksellik-Güvenlik Değerleri ile İlgili Turist Davranışları

48 yaşındaki Fransız finans analisti olan bir turist, "kendiniži VIP gibi hissediyorsunuz" demiștir ve şu şekilde devam etmiştir: "şehrin siz̨e kalması kesinlikele eşsį bir deneyim. Tüm sergileri kalabahk olmadan görmek harika. VIP gibi hissediyorsunuz ve çok güvenli hissettiriyor” (Gazete Duvar, 2020).

Bu durum; "uyarllm", "geleneksellik" ve "güvenlik" kişisel değerleriyle ilgili olmaktadır. "Uyarlım" ile ilgili olarak; turistin kendisini çok önemli kişi (VIP) gibi hissetmesi bir heyecan yaşamasını sağlamıștır. Şehrin turistlere kalması ise turistlere eşsiz bir deneyim yaşatmıştır. "Geleneksellike" ile ilgili olarak; sergilerin turistler tarafindan gezilmesi, turistlerin kültüre ve tarihe önem verdiğini göstermektedir. "Güvenlik" ile ilgili olarak; turist kendisini çok güvende hissetmektedir. 
Tema 6: Güç-Hedonizm-Kendini Yönlendirme-Geleneksellik Değerleri ile İlgili Turist Davranışları

Kapalıçarşı, İstanbul ilinin en tarihi bölgesinde bulunmaktadır. Beyazıt, Nuruosmaniye ve Mercan semtlerini birleştiren Kapalıçarşı, dünyanın en büyük ve en eski kapalı çarşılarından birisi olma unvanına sahiptir. Takriben 4.000 dükkânın bulunduğu Kapalıçarşı, aynı zamanda senede 91 milyon turisti ağırlamaktadır. Bu özelliği de Kapalıçarşı'yı dünyanın en çok ziyaret edilen turistik mekânı yapmaktadır (JOLLY, 2018).

Bu durum; "güç", "bedonizm", "kendini yönlendirme" ve "geleneksellik" kişisel değerleriyle ilgili olmaktadır. "Güg" ile ilgili olarak; Kapalıçarşı’nın dünya üzerinde bulunan en büyük ve eski kapalı çarşılarından bir tanesi olması, Kapalıçarşı'nın saygınlık kazanmasını ve turistler üzerinde turistik ve ekonomik yönde bir hâkimiyet oluşturmasını sağlamaktadır. "Hedoniz̧m" ile ilgili olarak; Kapalıçarşı'da bulunan dükkânlarda satılan çeşitli ürünlerin satın alınmasıyla turistlerin mutlu olduğu tahmin edilmektedir. Kapalıçarşı, ticaret açısından ve turistik açıdan önemli bir potansiyeli kendisinde barındırmakta, turistlerin istek-ihtiyaçlarını yerine getirme konusunda önemli bir kaynaklık etmektedir. "Kendini yönlendirme" ile ilgili olarak; turistler, Kapalıçarşı'ya ziyaretlerde bulunurlarken fikir ve eylemlerinde özgür oldukları ve kendilerini yönlendirdikleri düşünülmektedir. "Geleneksellike” ile ilgili olarak; Kapalıçarşı'nın oldukça tarihi bir bölgede yer alması, turistleri bu alana ziyaret etmeye teşvik etmektedir. Kapalıçarşı'nın dünya üzerinde bulunan en büyük ve eski kapalı çarşılardan bir tanesi olması da gerek turistik gerek kültürel gerekse de tarihi yönden turistlerin ilgisini çekmekte, bu alana fazla oranda turistik hareketlerin yaşanmasını sağlamaktadır.

Tema 7: Güç-Evrensellik-Geleneksellik-Uyumluluk-Güvenlik Değerleri ile İlgili Turist Davranışları

İstanbul İl Kültür ve Turizm Müdürü olan Dr. Coşkun Yılmaz, "İstanbul mimari eserleriyle, yani taribi mirasyla, farkh dinlere, farkh kültürlere, farkh dönemlere ait eserleriyle, tabiatylla, stratejile konumuyla, boğazzyla, doğal güzelliğiyle, turižn bizmet sektörïyle, gastronomisiyle, sportif alanlaryla, fuar imkânlaryla, kongre turizmi imkânlaryla ve sağhlk altyapısyyla bakttğmmıda dünyanin pek çok şehrinde olmayan bir bütünlïğe sabip. Dolayssiyla İstanbul, turistlere; dünya turizmi açssndan dünyanm bemen hemen hiçbir şehrinin sağlamadĭg bir imkân sağhlyor. İstanbul dünyada hiçbir șehrin sabip olmadĭg bir taribi tecrübeye sahip. Dünyada pek çok mezhep ve mesrep birbiriyle savas halinde iken, ayn dine, ayn millete, ayn ülkeye mensup topluluklar birbiriyle savas halinde iken; İstanbul'da tabiri caizse 72 millet farkli toplumlar, farkh inanclar, farkh messepler, farkh kültürler bir arada ve buzur içinde yassyordu. Bu anlamda dünyaya mubtesem bir sekilde bir arada yassama kültürünü sunuyor Istanbul" ifadelerini kullanmıştır (T.C. İstanbul Valiliği, 2019).

Sultanahmet Meydanı'nın bir arada yaşama kültürünün en büyük göstergesi olduğunu da ifade eden Dr. Yllmaz, "bu meydan Roma Imparatorluğu gibi dünyanm en büyü̈k devletlerinden ve medeniyetlerinden birine ev sahiplï̆i yaparken aym zamanda Osmanl Imparatorluğu gibi dünyanm en büyülk, en gü̈lü devletlerinden ve medeniyetlerinden birine ev sabipliği yapayor. Dünyanm hangi șebrinde Ayasofya ve Sultanahmet gibi iki aym inanon, iki ayn medeniyetin, iki ayn kültürün abidesini birbirini selamlarken görebilirsiniz: Dünyann hangi şebrinde elde edilen arkeolojik. bulgular, o sehrin 10 bin ynlina ve hatta baz? kažlarn sonuçlarna göre 300 bin yallhk geçmişine işaret eder. İstanbul taribi derinliği etki alanmmn genişliği ve süreklilï̆gi itibariyle dïnyada biçbir șehrin sabip olmadığ bir birikime sabiptir" (T.C. İstanbul Valiliği, 2019).

Bu durum; "güç", "evrensellik", "geleneksellik", "uyumluluk" ve "güvenlik”" kişisel değerleriyle ilgili olmaktadır. "Gü̧" ile ilgili olarak; farklı medeniyetlerin ve kültürlerin etkisini bünyesinde taşıyan insanların İstanbul'da huzur ve saygınlık ortamına zarar vermedikleri ifade edilmektedir. Bu durum da İstanbul'daki toplumsal itibarın da zedelenmemesi açısından önemli görüldüğü belirtilebilir. Bu durumdan yola çıkarak da İstanbul'un sosyal yönden güçlü bir destinasyon olduğu, yüksek seviyede bir otoriteye sahip olduğu ifade edilebilir. "Evrensellike" ile ilgili olarak; çeşitli toplulukların, çeşitli inançların, çeşitli meşreplerin, çeşitli kültürlerin İstanbul'da huzur ortamı içinde bir arada yaşadığı belirtilmektedir. Bu durumun ise evrensellik kişisel değeriyle ilgili bir paralellik gösterdiği düşünülmektedir (çünkü barış içinde-güzel bir dünyada yaşamayla ilgili benzer bir fikir söz konusu olmaktadır). "Geleneksellik" ile ilgili olarak; İstanbul ili, tarihi miras1, farklı uygarlıklara, dinlere, inançlara, kültürlere ait olan önemli eserleri sayesinde pek çok turisti kendisine çekebilme özelliğine sahip olmaktadır. Turistler açısından kültürel, turistik ve dini ögeler önem taşımaktadır. "Uyumluluk" ile ilgili olarak; İstanbul'daki turistlerin farklı kültürlere, medeniyetlere, inançlara sahip kişilerin bir arada, huzur içinde yaşadığı ve birbirleriyle uyum içerisinde yaşamlarını devam ettirdikleri ifade edilebilir. "Güvenlike” ile ilgili olarak; İstanbul önemli ve güvenilir bir destinasyon olduğu için, özellikle turistik anlamda güven ortamının korunması için çalşsılmaktadır. İstanbul'daki pek çok farklı 
medeniyetlere, kültürlere ve inançlara sahip olan insanların huzur içinde ve birbirleriyle uyumlu olması da güvenlik kişisel değerini vurgulamaktadır.

Moskova'dan gelen 36 yaşındaki bir turist, "antikoru olduğu için kendini güvende hissettiğini" söylemiştir. Turist, Türkiye'de Rusya'ya nazaran daha çok insanın maske kullandığını dile getirmiştir (Gazete Duvar, 2020).

Bu durum; "güc", "evrensellik" ve "güvenlik" kişisel değerleriyle ilgili olmaktadır. "Gǚs" ile ilgili olarak; Türkiye'de Rusya'ya göre daha fazla maske kullanımının olduğu ifade edilmektedir. Maske kullanımı konusunda Türkiye Rusya'ya göre daha fazla otorite sahibi olmaktadır. "Evrensellik" ile ilgili olarak; insanların sağlığını ve refahını muhafaza etmek amacıyla maske kullanımının yapıldığı göze çarpmaktadır. Ayrıca, Koronavirüs hastalığından yoksun ve güzel bir hayat, uygun koşul sağlanmaya çalışılmaktadır. "Güvenlik," ile ilgili olarak; Koronavirüs hastalığının bulaşmaması için maske önleminin alınması önemlidir. Bu önlem, can güvenliğinin sağlanması için önem arz etmektedir.

İpar’ın (2011) çalışmasına göre; İstanbul iline ziyaret gerçekleştiren turistler, İstanbul kentini hem destinasyon markası bir kent olarak hem de kültür - tarih kenti olarak görmektedirler. Bu sonuç, turistler tarafinca olumlu olarak değerlendirilen başka destekleyici sonuçlarla beraber, temelde gayet önemli ve pozitif çerçevede değerlendirilecek bir haldir. Lakin, başka açıdan turistler tarafindan destinasyon markası olarak kabul gören İstanbul kentinin, sahip olduğu olumlu değerlendirmelerin yanı sıra, tüm çalışma ve projelere karşın giderilmemiş eksikleri olmaktadır. Turistler tarafinca algılanan olumlu tarafların dağılımının yalnızca iki öge üzerine yoğunlaşması, alt yapı problemlerinin bulunduğunun ifade edilmesi ve üst yapı olarak da olumsuz ve kararsız yanıt verenlerin yer alması, İstanbul kentinin büyük çapta, trafik ve düzensiz kentleşme problemi olduğunun turistler tarafinca vurgulanması, turizm-ekonomik alanlar gibi hallerde eşitlik olduğunda, İstanbul kentinin dünyadaki başka marka destinasyonların yerine tercih edilirliğinin düşük olması sonucu ve İstanbul kentindeki turistik ögelere dair turistlerin bazı kararsızlıklarının olması, İstanbul kentinin güçlü bir destinasyon markası durumuna gelmesi için, düzeltilmesi gereken birden fazla problemin bulunduğunu göstermektedir.

İstanbul'un bir destinasyon markası ve kültür-tarih şehri olarak görülmesi ile "geleneksellik" kişisel değerinin birbirleriyle ilgili olduğu düşünülmektedir. İstanbul'da alt yap1 problemlerinin bulunduğunun ifade edilmesi, ilin üst yapısına dair olumsuz ve kararsız yanıtların bulunduğu, trafik ve kentleşme gibi sorunların bulunduğunun ifade edilmesi, kişisel değerlerden olan "güç" ile ilgilidir. Çünkü sosyal güç, zenginlik, otorite gibi örnek değerler bu kapsamda konuyla ilgili olmaktadır. Turistlerin olumlu, olumsuz ya da kararsız bütün yanıtlarını açik düşünceyle belirttiği ve bu durumun da "evrensellik" kişisel değeriyle bir benzerlik gösterdiği düşünülmektedir. Turistlerin verdikleri yanıtları açık düşünceli olarak verdikleri göz önünde bulundurulmaktadır. İstanbul destinasyonunun daha iyi bir destinasyon haline gelebilmesi için turistlerin yanıtları da son derece önemli olmakta ve bu durum da evrensellik kişisel değeriyle yakından ilgili olmaktadır.

Tema 8: Hedonizm-Geleneksellik-Uyarılım-Güvenlik Değerleri ile İlgili Turist Davranışları

İstanbul İl Kültür ve Turizm Müdürlügü’nün (2016) 'İstanbul Turizmi Turist Profili ve Davranıslar Araștrması" isimli ve İstanbul'a gelen 1067 yabancı turist üzerinde yaptığı çalışmaya göre; " $b u$ ziyaretinizle ilgili İstanbul'u bir duygu ile tarif etseniz, bu duygu ne olurdu?" sorusuna 1027 kişi yanıt vermiş olup yanttlar şu şekildedir: mutlu (\% 17,8), şaşırtıc1 (\% 9,4), güzel $(\% 8,8)$, tarihi $(\% 6,7)$, iyi $(\%$ 6,6), hoş ( $\%$ 6,5), heyecan verici $(\% 5,9)$, neşeli $(\% 4,2)$, rahat/ev gibi $(\% 4,2)$, muazzam/muhteşem (\% 3,9), ilginç (\% 3,3), kaotik/kalabalık (\% 3,0), harika ( $\% 2,5)$, canlı ( $\%$ 2,1), âşı olmak/romantik (\% 1,9), sürprizlerle dolu (\% 1,3), memnuniyet verici $(\% 1,2)$, ilham verici $(\% 1,1)$, sakin $(\% 1,0)$, diğer $(\% 8,8)$.

Turistlerin ifade ettikleri; mutlu, güzel, iyi, hoş, neşeli, rahat/ev gibi, muazzam/muhteşem, harika, canlı, âşı olmak/romantik, memnuniyet verici ve ilham verici duygular "bedonizm" kişsel değeriyle ilgili olmaktadır. Turistlerin ifade ettikleri; tarihi duygular "geleneksellik" kişisel değeriyle ilgilidir. Turistlerin ifade ettikleri; şaşırtıcı, heyecan verici, ilginç ve sürprizlerle dolu duygular "uyarllm" kişisel değeriyle ilgilidir. Turistlerin ifade ettikleri; kaotik/kalabalık ve sakin duygular "güvenlik" kişisel değeriyle ilgilidir. Kaotik/kalabalık duygusu güvenlik açısından olumsuz olarak yorumlanırken, sakin duygusu ise güvenlik açısından olumlu olarak yorumlanmaktadır. 
İstanbul ilinin en tarihi noktası hiç şüphe yok ki Sultanahmet Meydanı olmaktadır. Her gün dünyanın birden fazla yerinden turist konuk eden Sultanahmet Meydanı'nın tarihi, Roma devrine değin uzanmaktadır. Tarihinde hipodrom olarak değerlendirilen Sultanahmet Meydanı'nın bir başka adı da bu nedenle At Meydanı olarak da bilinmektedir. Birden fazla aktivite, spor müsabakaları ve gösterilerin gerçekleştirildiği Sultanahmet Meydanı'nda ilk göze çarpan durak ise dikilitaş olmaktadır. Sultanahmet Meydanı'nın tam ortasında bulunan dikilitaş hipodromu ikiye böler biçimde dikilmiştir. Bu taşın çevresinde yarışçılar 7 defa döner ve başlangıç noktasına ilk varan yarışı kazanırmış. Dikilitaşlar içerisinde öne çıkan Obelisk, 390 senesinde Mısır'dan getirilmiş ve tam 31 günde şimdiki yerine dikilmiştir (JOLLY, 2018).

Bu durum; "bedonižn" ve "geleneksellik" kişisel değerleriyle ilgili olmaktadır. "Hedonižm" ile ilgili olarak; Sultanahmet Meydanı'nda yapılan birçok aktivite, spor müsabakası ve gösterilerin turistleri memnun ve mutlu ettiği tahmin edilmektedir. "Geleneksellik" ile ilgili olarak; Sultanahmet Meydanı'nda düzenlenen etkinlik ve aktivitelerin kültürel ve turistik anlamda önemli olduğu, bu meydanda bulunan somut bir yap1 olan Obelisk dikilitaşının da tarihi bir değere sahip olduğu ifade edilebilir. Sultanahmet Meydanı'nı dünyanın birçok yerinden turistin ziyaret ettiği bilinmektedir.

Tema 9: Hedonizm-Güç-Başarı-Geleneksellik-Kendini Yönlendirme Değerleri ile İlgili Turist Davranışları

"İstanbul Turizmi Turist Profili ve Davranıslarn Araștırması" isimli çalışma, 2016 yllı ilk sekiz ayında İstanbul iline gelen yabancı ziyaretçilerin toplam ziyaretçiler içindeki milliyet payları dikkate alınarak; 99 çeşitli ülke vatandaşı ziyaretçiyle yüz yüze görüşülerek toplam 1067 anket uygulanarak gerçekleştirilmiştir. Bu çalışmayla, İstanbul'a gelen yabancı ziyaretçilere dair bazı bilgiler şöyle ifade edilmektedir (İstanbul İl Kültür ve Turizm Müdürlüğü, 2016);

- \% 66 oranında "tatil, seyahat, eğlence" için, \% 14 oranında "iş, kongre, toplantı" için, \% 10 oranında da "arkadass, akraba ziyareti" için gelmekte oldukları,

- En fazla gezip gördükleri yerlerin ilk sırasında "Boğaそ," ikinci sırasında "ístiklal Caddesi” ve üçüncü sirasinda "Sultanahmet Camii" olduğu,

- İstanbul iline ilişkin fikirlerinin \%95'e yakın oranda pozitif olduğu,

- \%96,4’ünün İstanbul'a tekrardan gelebileceği fikrine sahip olduğu görülmektedir.

Turistlerin eğlence amaçlı ziyaretleri, "bedonizm" kişisel değeri ile, iş, kongre ve toplantı amaçlı ziyaretleri de "güç" ve "başarı" kişisel değerleri ile, arkadaş, akraba ziyaretleri için gelenlerin ise "geleneksellike" kişisel değeriyle ilgili bir paralellik göstermektedir. Yapılan ziyaretlerin, kültür ve geleneklerin bütününde özel bir yeri bulunmaktadır. İstanbul'da en fazla gezilip görülen yerin sırasıyla; Boğaz, İstiklal Caddesi ve Sultanahmet Camii olduğu görülmekte ve bu yapiların da kültürel ve turistik yönden önem arz ettiği ifade edilmektedir. Dolayısıyla da bu durumun geleneksellik kişisel değeriyle ilgili olduğu öne sürülebilir. İstanbul'a tekrardan gelebileceği fikrine sahip olanlarla, "kendini yönlendirme" kişisel değeri arasında bir bağ bulunmaktadir.

Tema 10: Güç-Hedonizm-Kendini Yönlendirme-Geleneksellik-Güvenlik Değerleri ile İlgili Turist Davranışları

Ülkelere göre Türkiye'yi tercih eden turistlerin davranış kalıpları önemli olarak görülmekte ve şöyle ifade edilmektedir (Turizm Günlügü, 2019):

- Alman turistlerin tatil yapmak için Türkiye'yi tercih etmelerinin en önde gelen nedenleri arasında otel ve hizmet kalitesi, fiyat ve nispeten uçuş mesafesi, misafirperverlik gelmektedir. Trendlere ve beklentilere bakıldığında; güvenlik, hijyen, otel ve hizmet kalitesi, fiyat önemini muhafaza ederken, aktif tatil ile seçenek turizm olanakları ve ulaşım gibi konular git gide önem kazanmaktadır. Alman turistler Kapadokya, Muğla, Antalya ve İstanbul'u tercih etmektedirler.

- Belçika yurttaşları, gidecekleri varış yerinin hava durumuna dair realist bilgilere sahip olmak, havayolu ile basit ve hızlı bir biçimde ulaşım gerçekleştirmek ve planlayacağı tatil hususunda aradıkları her bilgiye internetten ulaşabilmek istemektedir. Spor, eğlence, kum, deniz ve güneş kombinasyonu, Belçikalıların ağırlıklı olarak tercih sebebi olurken; arkeolojik yapıtların sergilendikleri müzeleri ve tarihi yapıları olan kent gezilerini de sevmektedirler. Belçikalıların, 
Türkiye'ye seyahat ettiklerinde tercih ettikleri varış yerleri sırası ile Antalya, İstanbul, Muğla, Kapadokya, İzmir, Aydın, Denizli olmaktadır.

- İtalyanların yurt dışı seyahatlerinde temel iki gayesi; değişik kültürleri tanımak ve deniz tatili yapmaktır. Kültür maksatlı seyahatlerinde tarihi bağlar, ülkenin ucuz olması, hizmet kalitesi varış yerini saptamada önemli birer etken olmaktadır. Deniz tatilindeyse yine ülkenin ucuz olması, hizmet kalitesi, uygun iklim şartları önemli etkenlerdir. İtalyanlar, her şey dâhil sistemine yap1 olarak pek uygun olmamaktadırlar. Deniz tatillerinde bile seyahat ettikleri ülkenin kültürünü görmek ve yaşamak istemektedirler. İtalyanların Türkiye tercihlerinde Antalya, İzmir, İstanbul, Denizli, Bodrum, Fethiye, Kapadokya, Kuşadası destinasyonları öne çıkmaktadır.

İstanbul'u tercih eden turistlerin davranış ve tutumları çoğunlukla "güç", "bedonižm", "kendini yönlendirme", "geleneksellik" ve "güvenlik" kişisel değerleriyle ilgili olmaktadır. "Gǚs" ile ilgili olarak; turistler için sosyal yönden güçlü, farklı özelliklere sahip, ürün ve hizmetlerinde çeşitlilik ve alternatifleri olan turistik bölgeler önemli olmaktadır. "Hedonizm" ile ilgili olarak; turistlerin eğlence, haz alma ve sevme davranış ve duygularının görüldüğü ifade edilmektedir. "Kendini yönlendirme" ile ilgili olarak; turistlerin farklı istek, ihtiyaç ve karakter yapılarına bağlı olarak da kendilerini yönlendirdikleri görülmektedir. "Geleneneksellik" kişisel değeriyle ilgili olarak; turistler açısından kültür, tarihi bağlar ve misafirperverlik önemlidir. Ayııca turistler tarafından değişik kültürleri tanımak, arkeolojik yapıtlar sergilenen müzeleri ve tarihi yapıtları olan kentleri gezmek de geleneksellik kişisel değerinin önemine vurgu yapmaktadır. "Güvenlik" ile ilgili olarak; turistler tarafindan güvenlik unsurunun önemli olduğu ifade edilmektedir.

\section{Tartışma, Sonuç ve Öneriler}

Kişisel değerler, genel olarak bireyin sahip olduğu fikir, inanç ve kuralları biçiminde belirtilmektedir. Bireyin sahip olduğu değerler var olma amacı ve davranışlarına yön vermektedir. Bu sebeple tüketici davranışlarına açıklık getirmede önemli ögelerden bir tanesidir (Ünal vd., 2008, s. 211). Nitekim bu çalışmada da kişisel değerler turist davranışlarına açıklık getirmede önemli bir öğe olma rolü üstlenmiştir. Ayrıca turistlerin kişisel değerlerine göre bir yönelim gösterdiği sonucu ortaya çıkmıştır. Bu konuya paralel olarak da Schwartz (1994, s. 19-45) kişisel değerlerin, insanların kişisel yönelimlerini belirlediğini ve herhangi bir seçim kararında etkin olduğunu belirtmiştir.

Kişisel değerler, insanların hayatlarında önemli olanın ne olduğunu açıklamaktadır. Kişisel değerler bu bakımdan çok sayıda olup, birbirinden farklı olmaktadır. Aynı zamanda insanlar, farklılaşan önem derecelerinde çok sayıda değere sahip olabilmektedirler (Bardi ve Schwartz, 2003, s. 1207-1220). Bu çalışmada ise turistlerin davranışlarında hangi kişisel değerlerin ön plana çıktığı ve önemli olduğu vurgulanmiştır.

Tüketici, sahip olduğu kişisel değerlerle benzeri davranışlar göstermektedir (Erciş, Yapraklı, Can ve Y1lmaz, 2013, s. 21). Bu çalışmada da turistlerin çoğunlukla önem verdikleri kişisel değerlere göre hareket ettikleri ortaya çıkmışır.

Turistlerin yoğun olarak bulunduğu destinasyonlar arasında İstanbul gelmektedir. İstanbul destinasyonu, sahip olduğu pek çok doğal, kültürel, tarihi ve turistik kaynakları sayesinde yerli-yabanc1 turistleri kendisine çekmektedir. Bundan dolayı, İstanbul destinasyonuna yönelik turistik çalşmaların sayılarının artırılması ve kalitelerinin geliştirilmesi önem arz etmektedir.

$\mathrm{Bu}$ araştırma kapsamında, kişisel değerler odaklı turist davranışları ele alınmış, araştırma bulguları uygun bir șekilde sınıflandırılmış ve bu sınıflandırma sonucunda 10 tema ortaya çıkmıștır. "Hedoniẓ̌m” ve "geleneksellike" kişisel değerlerinin turist davranışlarında ön plana çıktığı görülmektedir. Bu durum turistlerin çoğunlukla mutlu olmak, haz almak ve kültürel, tarihi, dini, turistik vb. gibi açılardan kendilerini tatmin etmeyi sağlama amacında olduklarını gözler önüne sermektedir. Turistlerin düşünce, davranış, duygu ve tutumlarının net bir şekilde anlaşılması, turistlerin memnuniyet ve sadakatinin sağlanmasında önemli olarak görülmektedir.

Bu çalışma İstanbul ili ile sınırlandırılmış bulunmaktadır. Bundan sonra konuyla ilgili çalışma gerçekleştirecek olan kişilere çalışmalarını Antalya ili üzerine yapmaları önerilmektedir. Ayrıca aynı konu, Türkiye’nin Akdeniz Bölgesi’nde yer alan iller üzerine uyarlanarak da yapilabilir.

$\mathrm{Bu}$ araştırma sonucunda ortaya çıkan ve önemli olarak görülen sonuçlar şu şekildedir; 
"Hedoniæ̧m" kişisel değeri, mutlu olma ve haz alma açısından önemli olmakta ve çalışmada öne çıkan hazcılık kişisel değeriyle ilgili ayrıntılar şöyle olmaktadır: İstanbul'un havasından ve yapılan alışverişlerin cazip olmasından dolayı zevk alındığı belirtilmektedir. İstanbul şehri turistlerin hoşuna gitmekte, burada bulunmaktan dolayı mutluluk duyulmakta ve şehirdeki otellerin modern olduğu ifade edilmektedir. Alışveriş imkânları açısından İstanbul'un güzel bir yer olduğu ifade edilmektedir. Alışveriş eylemlerinin kişileri mutlu ettiği tahmin edilmektedir. İstanbul'un çok güzel bir şehir olduğu ifade edilmekte ve buradaki dondurmalar çok beğenilmektedir. İstanbul'da düğün ve eğlenceler yapilmakta, Türkiye'de bulunulmaktan dolayı mutluluk duyulmaktadır. Türk insanları sevilmektedir. Turistler Sultanahmet bölgesini gezmeyi sevmektedir. Turistler güneşin tadının çıkarmak istemektedir. Yapıldığı dönemlerin estetik güzelliğini aksettiren İstanbul'daki bazı yapılar turistlerin ilgi odağı durumunda olmaktadır. Bu yapıların da özellikle estetik açılardan turistlere güzel bir duygu hissettirdiği ve onları mutlu ettiği düşünülmektedir. Turizm, gastronomi, sağllk gibi yönlerden İstanbul turistlerin ilgisini üzerine çekebilecek bir şehir olmaktadır. Söz konusu yönlerin, turistlerin hayattan zevk alması ve mutlu olması üzerinde bir etkiye sahip olduğu tahmin edilmektedir.

"Geleneksellik" kişisel değeri, kültürel, tarihi, dini, turistik vb. açılardan önemli olmakta ve çalışmada öne çıkan geleneksellik değeriyle ilgili ayrıntılar şöyle olmaktadır: İstanbul'un doğal güzelliği ve tarihi dokularıyla yerli ve yabancı turistleri etkilediği ifade edilmektedir. Turistler, İstanbul ili hakkında dünyanın en güzel ve büyüleyici kentlerinden bir tanesi olarak söz etmektedir. Bu durumda kültürün ve tarihi dokunun da etkili olduğu düşünülmektedir. Sergilerin turistler tarafindan gezilmesi, turistlerin kültüre ve tarihe önem verdiğini göstermektedir. Kültürel ve tarihsel açıdan çok öneme sahip olan İstanbul, bu yönüyle yerli ve yabancı turistlerin ilgisini çekmektedir. Topkapı Sarayı'nda yer alan pek çok tarihi, turistik ve kültürel niteliğe sahip olan değerler turistler için önemli olarak görülmektedir. Turistler, bu söz konusu değerleri görmek ve yakından tanımak için Topkapı Sarayı'nı ziyaret etmektedir. Ülke, bölge veya yörelerin sanat ve kültürlerini tanımayı arzu eden turistlerin odak noktasında ise gelenekselliğin bulunduğu ve merak unsurunun ön planda olduğu düşünülmektedir. Turistler açısından kültürel, turistik ve dini ögeler önem taşımaktadır. İstanbul'un İslamiyet, Hristiyanlık ve Musevilik dinlerinden önemli emareler taşıması, bu destinasyona ait olan turizm talebini artırma noktasında bir etkiye sahiptir. Türkiye'nin en ünlü caddelerinden birisi olan İstiklal Caddesi, turistlerin ziyaret ettikleri alanlar arasında bulunmaktadır. İstiklal Caddesi üzerinde pek çok somut yapı yer almaktadır. Bu somut yapıların ise; kültürden, gelenekgörenekten, tarihten çeşitli izler taşıdığı ifade edilebilir. Turistler, bu somut yapıları gezmek, görmek ve tanımak istemektedir.

"Kendini yönlendirme” kişisel değeri, düşünce ve davranışı gerçekleştirme aşamasında önemli olmakta ve çalışmada öne çıkan kendini yönlendirme değeriyle ilgili ayrıntılar şöyle olmaktadır: turistler düğün yapmak, boğaz ve ada turu yapmak istemektedir. Türklerin Arap turistleri sevmediği düşünülmekte ve söz konusu durumda da Arap turistleri üzmektedir. Suriyelilerin Arap turistlerin akıllarında olumsuz olarak kaldığı da belirtilmektedir. İstanbul, meraklı olan, öğrenmeyi arzu eden, istifade etmeyi düşünen, görmek isteyen kısacası ise kendi hedeflerini seçen, kendilerini yönlendirmek isteyen turistlerin ilgisini çekecek potansiyele sahip bir ildir.

"Uyarlım” kişisel değeri, heyecan ve farklıı yaşama açısından önemli olmakta ve çalışmada öne çıkan uyarılım değeriyle ilgili ayrıntılar şöyle olmaktadır: Kuveytli turistler, Büyükada'da faytonla tur atmakta ve ilginç deneyimler yaşamaktadırlar. İstanbul Boğazı, güzelliği ve dünyanın hiçbir yerinde bulunmayan bir doğal yapısıyla konukların zihinlerinde unutulmaz bir iz bırakmaktadır. Yerli turistler hediyelik eşyaların farklılaştııllmasını, sonrasında yapılacak olan hediyeliklerin zanaatkârlar aracilığılla yapılmasını ve bölgeye has olmasını beklemektedir.

"Güvenlik" kişisel değeri, huzur ve güven ortamının sağlanması ve korunması açısından önemli olmakta ve çalışmada öne çıkan güvenlik değeriyle ilgili ayrıntılar şöyle olmaktadır: turistler tarafindan İstanbul içinde güvende hissedilmektedir. İstanbul, önemli ve güvenli bir destinasyon olarak görülmekte, özellikle turistik anlamda güven ortamının korunmasının turistler açısından önemli olduğu düşünülmektedir.

Bazı kişisel değerlerin iç içe bulunduğu durumlar olmaktadır. Bu durumlar da şöyle açıklanmaktadır: "güç" ve "geleneksellik" kişisel değerlerinin iç içe bulunduğu durumlar bulunmaktadır. Geleneksellik değerinin önceden kısa açıklaması yapılmıştır. Güç değeri ise, insan ve kaynaklar üzerine hâkimiyet kurma, saygınlık, sosyal statü, otorite vb. gibi bakımlardan önem taşıyan bir değerdir. Çalışmada öne çıkan güç ve geleneksellik kişisel değerleri ile ilgili ayrıntılar şöyle olmaktadır: Kapalıçarşı'nın dünya üzerinde bulunan en 
büyük ve eski kapalı çarşılarından bir tanesi olması, Kapalıçarşı'nın saygınlık kazanmasını ve turistler üzerinde turistik ve ekonomik yönde bir hâkimiyet oluşturmasını sağlamaktadır. Kapalıçarşı'nın oldukça tarihi bir bölgede yer alması, turistleri bu alana ziyaret etmeye teşvik etmektedir. Kapalıçarşı'nın dünya üzerinde bulunan en büyük ve eski kapalı çarşılarından bir tanesi olması da gerek turistik gerek kültürel gerekse de tarihi yönden turistlerin ilgisini çekmekte, bu alana fazla oranda turistik hareketlerin yaşanmasını sağlamaktadır. "Kendini yönlendirme" ve "geleneksellik" kişisel değerlerinin iç içe bulunduğu durumlar olmaktadır. Bu iki değerin önceden kısa açıklaması yapılmıştır. Çalışmada öne çıkan kendini yönlendirme ve geleneksellik kişsel değerleri ile ilgili ayrıntılar şöyle olmaktadır: İstanbul'un bilim, kültür ve sanatta önemli bir şehir olduğu ve turistleri kendisine çektiği ifade edilebilir. Evde kalmaktan dolayı sıkılan turistler farklı kültürlere sahip bir yeri görmek için gidecekleri yeri seçmektedirler. Turistler için farklı kültürleri tanımak önemlidir. "Hedoniz̧m" ve "geleneksellik" kişisel değerlerinin iç içe bulunduğu durumlar olmaktadır. Bu iki değerin önceden kısa açıklaması yapılmışır. Çalışmada öne çıkan hazcılık ve geleneksellik kişisel değerleri ile ilgili ayrıntılar şöyle olmaktadır: İstanbul'un estetiksel güzelliği turistleri mutlu etmektedir. Dünyanın en güzel ve büyüleyici şehirlerden birisi olduğu ifade edilen İstanbul'un, kültür ve tarihinin de turistlerin bu fikirlerinin oluşmasında etkili olduğu düşünülmektedir. Sultanahmet Meydanı'nda yapılan birçok aktivite, spor müsabakası ve gösterilerin turistleri memnun ve mutlu ettiği tahmin edilmektedir. Sultanahmet Meydanı'nda düzenlenen etkinlik ve aktivitelerin kültürel ve turistik anlamda önemli olduğu, bu meydanda bulunan somut bir yapı olan Obelisk dikilitaşının da tarihi bir değere sahip olduğu ifade edilebilir. Sultanahmet Meydanı'nı dünyanın birçok yerinden turist ziyaret ettiği bilinmektedir. "Kendini yönlendirme" ve "g̈̈venlike" kişisel değerlerinin iç içe bulunduğu durumlar olmaktadır. Bu iki değerin önceden kısa açıklaması yapılmıştır. Çalışmada öne çıkan kendini yönlendirme ve güvenlik değerleri ile ilgili ayrıntılar şöyle olmaktadır: turistler çoğunlukla bağımsız düşünceleriyle İstanbul'a gelmişlerdir. Türkiye'nin güvenli bir ülke olarak da hissedilmesi, turistin bu kararı almasında etkili olduğu tahmin edilmektedir. "Gǚc" ve "uyumluluk" kişisel değerlerinin iç içe bulunduğu durumlar olmaktadır. Güç değerinin önceden kısa açıklaması yapılmıştır. Uyumluluk değeri ise, uyum sağlama ve kontrolle ilgili bir değer olmaktadır. Çalışmada öne çıkan güç ve uyumluluk değerleri ile ilgili ayrıntılar şöyle olmaktadır: farklı medeniyetlerin ve kültürlerin etkisini bünyesinde taşıyan insanların İstanbul'da huzur ve sayginlık ortamına zarar vermedikleri ifade edilmektedir. "Evrensellik" ve "uyumluluk" kişisel değerlerinin iç içe bulunduğu durumlar olmaktadır. Uyumluluk değerinin önceden kısa açıklaması yapılmıştır. Evrensellik değeri ise, insanlık ve doğanın refahını muhafaza etmeyi ve anlamayı esas alan bir değerdir. Çalışmada öne çıkan evrensellik ve uyumluluk değerleri ile ilgili ayrıntılar şöyle olmaktadır: çeşitli toplulukların, çeşitli inançların, çeşitli meşreplerin, çeşitli kültürlerin İstanbul'da huzur ortamı içinde bir arada yaşadığı belirtilmektedir. "Evrensellik" ve "yardımseverlik" kişisel değerlerinin iç içe bulunduğu durumlar olmaktadır. Evrensellik değerinin önceden kısa açıklaması yapılmıştır. Yardımseverlik değeri ise, kişisel ilişki oluşturulan kimselerin refahını düşünmek ile ilgili olan bir değerdir. Çalışmada (olumsuz olarak) öne çıkan evrensellik ve yardımseverlik değerleri ile ilgili ayrıntılar şöyle olmaktadır: İstanbul'daki birtakım insanların davranışlarının rahatsız edici olması, garsonların güler yüzlü davranmaması, birtakım işletmelerde yeterince ilgilenilmemesi, taksicilerin fazla para talep etmeleri turistleri mutsuz etmektedir. "Güç" ve "başarn" kişisel değerlerinin iç içe bulunduğu durumlar olmaktadır. Güç değerinin önceden kısa açıklaması yapılmıştır. Başarı değeri, sosyal hayatta ya da sosyal standartlar doğrultusunda gösterilen bir kişisel başarıdır. Çalışmada öne çıkan güç ve başarı değerleri ile ilgili ayrıntılar şöyle olmaktadır: iş, kongre ve toplantı amaçlı ziyaretleri, güç ve başarı kişisel değerleri ile bir paralellik göstermektedir.

$\mathrm{Bu}$ araştırma sonucunda şu öneriler verilmiştir;

- Turizm hareketlerinin canlılık kazanmasında, turistlerin beklentilerinin karşılanmasında, turistlerin memnuniyetinin ve sadakatinin oluşturulmasında/artırılmasında, ülke veya destinasyon marka-imajının iyi bir izlenim elde etmesinde yerel halka ve turizm personeline önemli sorumluluk ve görevler düşmektedir. Yerel halkın ve turizm personelinin bu önemli görevleri layıkıyla yerine getirmeleri beklenmektedir.

- Turistlerin karşı karşıya kaldığı problemlerin en kısa zaman içerisinde giderilmesi gerekmektedir. Dil sorunları, trafik sorunları, hırsızlık ve dolandırıcılık, olumsuz ve kaba davranışlar, aşırı derecedeki kalabalık ortam, ulaşım hizmetlerinin yeterli olmaması ve beklentilere tam karşılık verememesi turistleri üzmekte, turistik hareketleri sekteye uğratmakta ve turizmi olumsuz yönde etkilemektedir. Söz konusu problemlere karşı insanların bilgilendirilmesi, bu konuda da en uygun çözüm yollarının oluşturulması/geliştirilmesi gerekmektedir. 
- Turistler; coğrafi güzelliklerden faydalanmak, kültürel anlamda bir etkileşim yaşamak, turizm ürünlerinden ve hizmetlerinden etkin bir şekilde faydalanmak istemektedirler. İlgili bölgede ya da destinasyonda gerçekleşecek her türlü olumsuz durum (sosyolojik, dini, psikolojik, çevresel, fiziksel, ekonomik vb. gibi gerçekleşecek olumsuz durumlar) turistleri kötü bir şekilde etkileyecek, bu durum da turistlerin davranış ve tutumlarına yansıyacaktır. Turist profillerinin çok iyi bir şekilde analiz edilmesiyle beraber, turizmde gözle görülebilir değişimlerin ve gelişimlerin yaşanacağ1 tahmin edilmekte, bu alana yoğunluk gösterilmesinin oldukça önemli olduğunun ssrarla altı çizilmektedir.

- Turistik ürün ve hizmetlerin daha çok tercih edilmesi için hedeflenen turist profilinin çok iyi bir şekilde analiz edilmesi ve bu kapsamda en uygun stratejilerin izlenmesi önemli olarak görülmekte, bu durum sonucunda da turistlerin memnuniyet ve sadakatinin daha fazla kazanılacağı ifade edilmektedir.

- Turistlerin hiçbir zaman kesinlikle bir firsat olarak görülmemesi gerekmektedir.

- Turizmde önemli bir yeri bulunan turistlerin kişisel davranışlarının akademik çalısmalarda daha fazla ele alınması, gerek sektöre gerekse de alan yazına önemli ölçüde katkılar sağlayacaktır.

- Turistlerin düşünce, davranış, duygu ve tutumlarının net bir şekilde anlaşılması, turistlerin memnuniyet ve sadakatinin sağlanmasında önemli olarak görülmektedir. Bu hususta önemli görülen uygulama ve projelerin faaliyete geçirilmesi önerilmektedir.

- Kişisel değerler, içsel iletişim ve sosyal iletişim kurulurken öne çıktığ düşünülen değerler olmaktadır. Bu değerler çerçevesinde turist davranışlarına açılık getirilmesi, turist davranışları konusuna farklı perspektiflerden bakma noktasında etkili olmaktadır. Turizmde daha fazla gelişme sağlanması için turist davranışlarına farklı açılardan ve daha yoğun bir şekilde odaklanılması gerektiği önerilmektedir.

- Turist davranışlarının temel noktasında yer alan problemlerin, direkt olarak kişinin özellikleri ve karakteriyle ilgili olduğu düşünülmektedir. Bu nedenle turistlerin kişilik özellikleri ve karakter yapılarının üzerine daha fazla yoğunlaşılması, bu anlamda daha çok fikirlerin, çalışmaların türetilmesi ve bu hususta da bütün turizm paydaşlarına önemli çağrıların yapılması gerektiği düşünülmektedir.

- Turistik ürün ve hizmetler açısından turistlerin beklentileri kişisel değerler odaklı olarak önceden öngörülebilmeli ve bunlara en uygun stratejiler izlenebilmelidir.

- Turistler ile iletişim kurulurken daha fazla dikkat edilmesi, iletişimi zedeleyici hal, hareket ve tavırlardan kaçınılması gerekmektedir.

- Turistler ve diğer kişiler birbirleriyle iletişimde bulunurlarken kişisel değerlere dikkat etmeli, sevgi ve saygı kuralları çerçevesinde bir yaklaşımda bulunmalı, adabımuaşeret kurallarına uygun davranışlar sergilemelidirler.

- Turistlerin rahatsız oldukları durumlar karşısında acilen çözüm yollarının üretilmesi gerekmektedir. Turistler olumsuz bir şekilde ortaya çıkan olaylar karşısında üzülmektedir. Bu olumsuz olaylar sonucunda; turistler psikolojik ve sosyolojik olarak kendilerini huzursuz ve mutsuz hissetmekte, bu durum bazen ülke, bölge ya da destinasyonun imajının zedelenmesine neden olmakta, turistlerin gözünde olumsuz bir izlenim oluşmasına yol açmakta, turizm sektöründen sağlanan gelirin azalmasına sebebiyet vermekte, ekonomik büyüme ve gelişmeye büyük zararlar vermektedir.

- Turistlerin beklentilerinin yerine getirilmesi konusunda pek çok unsurun ön plana çıkarılması gerektiği düşünülmektedir. Beklentileri karşılanmamış/karşılanamamış turistlerin tutum ve davranışlarında birçok olumsuzlukların görülmesi muhtemel olmaktadır. Turizm sektöründe çalışanların becerileri, yetenekleri, farklı dil bilgisine sahip olmaları, görgü ve nezaket kurallarına aykırı davranmama durumları (ki bu durum turizmde oldukça önem arz etmekte) önemli olarak görülmekte ve turizm hareketlerinin seyrini değiştirmektedir.

\section{Etik Beyan}

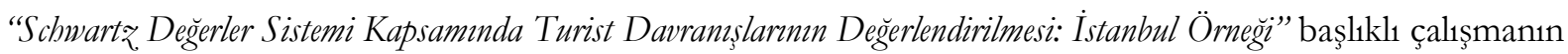
yazım sürecinde bilimsel kurallara, etik ve alıntı kurallarına uyulmuş; toplanan veriler üzerinde herhangi bir tahrifat yapılmamış ve bu çalışma herhangi başka bir akademik yayın ortamına değerlendirme için gönderilmemiştir. $\mathrm{Bu}$ araştırmada doküman incelemesi yapıldığından etik kurul kararı zorunluluğu bulunmamaktadir. 


\section{Kaynakça}

Akçin, N. (2019). Uzun süreli seyahatlerin katılımolar üzerindeki psikolojïk etkilerini belirlemeye yönelik bir araştırma (Yüksek Lisans Tezi). Sakarya Uygulamalı Bilimler Üniversitesi, Lisanüstü Eğitim Enstitüsü, Sakarya.

Akova, O. (2006). Yerel halkın turizmin etkilerini algılamalarına ve tutumlarına yönelik bir araştırma. Akademik Incelemeler Dergisi, 1 (2), 1- 34.

Akyurt, H. ve Atay, L. (2009). Destinasyonda imaj oluşturma süreci. Aksaray Üniversitesi İktisadi ve İdari Bilimler Fakültesi Dergisi, 1 (1), 1-14.

Bardi, A. ve Schwartz, S. H. (2003). Values and behavior: strenght and structure of relations. Personality and Social Psychology Bulletin, 29(10), 1207-1220.

Borsa Gündem. (2017). İstanbul'un her yeri Arap kayniyor, Erişim Adresi: https://www.borsagundem.com/haber/istanbulun-her-yeri-arap-kayniyor/1230872, Erişim Tarihi: 06.02.2021.

Corbin, J. ve Strauss, A. (2008). Basics of qualitative research: techniques and procedures for developing grounded theory. Thousand Oaks: Sage.

Costa, P. T. ve McCrae, R. R. (1992). Four ways five factors are basic. Personality and Individual Differences, 13(6), 653665.

Çolakoğlu, E., Türk, B., Başar, E. E. ve Gül, O. (2013). Kişisel değerler ve çevre bilincinin çevreci ürünlerin tercih edilmesindeki etkileri: karşılaştırmalı bir araştırma. Ulusal Pazarlama Kongresi, Kars/Türkiye.

De Her, J. ve Van Vliet, H. (2001). A means-end chain approach to next generation TV - A Consumer Research Pilot Study.

Demir, Ş. Ş. ve Kozak, M. (2011). Turizmde tüketici davranışları modelini oluşturan aşamalar arasındaki ilişki. Anatolia: Turizm Arastermalan Dergisi, 22(1), 19-34.

Doğan, H. Z. (2004). Turizmin sosyo-kültürel temelleri (2. Baskı). Ankara: Detay Yayıncılık.

Erciş, A. ve Türk, B. (2014). Kişisel değerler ve içsel yenilikçilik boyutları ilişkisinin yapısal eşitlik modeliyle incelenmesi. Ataturk University Journal of Economics and Administrative Sciences, 28(2), 75-88.

Erciş, A., Yapraklı, Ş., Can, P. ve Yılmaz, M. K. (2013). Kişisel değerler ile marka değeri arasındaki ilişkiler. Atatürk Üniversitesi İktisadi ve İdari Bilimler Dergisi, 27(2), 21-42.

Gazete Duvar. (2020). NYT, sokağa çıkma yasağından muaf tutulan turistlerle konuştu: İstanbul'a özel erişimimiz var, Erişim Adresi: https://www.gazeteduvar.com.tr/nyt-sokaga-cikma-yasagindan-muaf-tutulan-turistlerlekonustu-istanbula-Ozel-erisimimiz-var-haber-1506845, Erişim Tarihi: 06.02.2021.

Günlü, E. (2007). Turizm sosyolojisi ve turistik tüketici davranışları. O. İçöz (Ed.) içinde, Genel turiz̨m-turiz̧mde temel kavramlar ve ilkeler (s. 167-181). Ankara: Turhan Kitabevi.

Habertürk. (2020). İstanbul'da sokağa çıkma kısıtlaması yabanc1 turistlere yaradı, Erişim Adresi: https://www.haberturk.com/istanbul-da-sokaga-cikma-kisitlamasi-yabanci-turistlere-yaradi-2891072, Erişim Tarihi: 05.02.2021.

İpar, M. S. (2011). Turizmde destinasyon markalasması ve İstanbul üzerine bir uygulama (Yüksek Lisans Tezi). Balıkesir Üniversitesi, Sosyal Bilimler Enstitüsü, Balıkesir.

İstanbul İl Kültür ve Turizm Müdürlüğü. (2016). İstanbul turizmi turist profili ve davranışları araştırması, Erişim Adresi: https://istanbul.ktb.gov.tr/Eklenti/61249,turist-profili-ve-davranislari-arastirmasipdf.pdf?0, Erişim Tarihi: 06.02.2021.

Jafari, J. (Ed.). (2000). Encyclopedia of tourism. London - Newyork: Routledge.

Jamaludin, N. L., Sam, D. L., Sandal, G. M. ve Adam, A. A. (2016). Personal values, subjective well - being and destination - loyalty intention of international students. Springerplus, 5(720), 1-11.

JOLLY. (2018, 5 Ekim). İstanbul gezi rehberi: turist gözüyle İstanbul'u keşfediyoruz. [Blog Yazısı]. Erişim adresi: https://blog.jollytur.com/istanbul-gezi-rehberi/

Kahle, L.R. (1985). Social values in the eighties: a special issue. Psychology and Marketing, 2(4), 231.

Karakaş, A. ve Şengün, H. (2017). Yerel halkın turizm faaliyetlerine yönelik tutumları. Bartın Üniversitesi İ.I.B.F. Dergisi, 8 (15), 183-203.

Karataş, Z. (2015). Sosyal bilimlerde nitel araştırma yöntemleri. Manevi Temelli Sosyal Hið̧met Araștırmalar Dergisi, 1(1), 62-80.

Kıral, B. (2020). Nitel bir veri analizi yöntemi olarak doküman analizi. Sïrt Üniversitesi Sosyal Bilimler Enstitüsü Dergisi, 8(15), 170-189.

Lanquar, R. (1985). Turiz̧m-seyahat sosyolojisi. (Çev. G. Ö. Kayır). İstanbul: İletişim Yayınları.

Mehtap, Ö. (2016). Bireysel davranış, kişilik ve değerler. Günsel, A. ve Bozkurt, S. (Eds.) içinde, Örgütsel davranış (s. 22-43), Ankara: Nobel Akademik Yayıncılık Eğitim Danışmanlık.

Michael, S. ve John, U. (1988). Social studies for children. a guide to basic instruction. (9. Edition). NewJersey: Prentice Hall.

Milliyet. (2017). İstanbul'a körfez akını, Erişim Adresi: https://www.milliyet.com.tr/gundem/istanbul-a-korfez-akini2520906, Erișim Tarihi: 06.02.2021.

NTV. (2020). Yabanc1 turistler kendilerini İstanbul'da güvende hissediyor, Erişim Adresi: https://www.ntv.com.tr/seyahat/yabanci-turistler-kendilerini-istanbulda-guvende-hissediyor,jJs6zJJnUardfTwfy5msA, Erişim Tarihi: 06.02.2021.

Odabaşı, Y. ve Barış, G. (2007). Tüketici davranısıı. İstanbul: Mediacat. 
Opan, E. (2019, 24 Aralık). İstanbul'da Mutlaka Gezilmesi Gereken 50 Yer. [Blog Yazıs1]. Erişim adresi: https://blog.obilet.com/istanbulda-gezilecek-yerler/

Pearce, P. L. (2005). Tourist behaviour: themes and conceptual schemes. Clevedon: Channel View Publications.

Polat, S. A. (2013). Turistlerin tatil dönemlerinde sergiledikleri geçici davrantş değişsiklikleri (liminoid) üzerine bir araștorma. (Doktora Tezi). Sakarya Üniversitesi, Sosyal Bilimler Enstitüsü, Sakarya.

Rızaoğlu, B. (2003). Turiz̧m davranışı. (Birinci Baskı). Ankara: Detay Yayıncılık. ISBN: 978-975-8326-73-0.

Rokeach, M. (1973). The nature of human values. New York: The Free Press.

Saatc1, G. ve Avc1kurt, C. (2016). Cross-cultural tourist attitudes: a search within the scope of integrated threat theory. Itobiad: Journal of The Human and Social Science Researches, 5 (8).

Schwartz, S. H. (1994). Are there universal aspects in the structure and content of human values?. Journal of Social Issues, 50 (4), 19-45.

Schwartz, S. H. ve Bilsky, W. (1994). Values and personality. European Journal of Personality, 8(3), 163-181.

SÖZCÜ. (2020). Corona yasaklarından muaf tutulan turistler: İstanbul'da VIP gibiyiz, Erişim Adres: https://www.sozcu.com.tr/2020/ekonomi/the-new-york-times-istanbul-turklere-kapali-yabanciya-acik6160005/, Erişim Tarihi: 04.02.2021.

STAR. (2015). Dünya ve Türkiye turizminin başkenti İstanbul, Erişim Adresi: https://www.star.com.tr/yazar/dunyave-turkiye-turizminin-baskenti-istanbul-yazi-1074294/, Erişim Tarihi: 06.02.2021.

Sünbül, K. (2018). Turistlerin gıda güvenlïgi bilgisinin şikâyet etme davranışına etkisi. (Yüksek Lisans Tezi). Karabük Üniversitesi, Sosyal Bilimler Enstitüsü, Karabük.

T.C. İstanbul Valiliği. (2019). İstanbul'un turizm hedefine ulaşmasını hep birlikte sağlayacağı, Erişim Adresi: http://www.istanbul.gov.tr/istanbulun-turizm-hedefine-ulasmasini-hep-birlikte-saglayacagiz, Erişim Tarihi: 06.02.2021.

Takvim. (2021). Ortaköy'de turist yoğunluğu! Yağmura rağmen İstanbul'un tadını çıkardılar, Erişim Adresi: https://www.takvim.com.tr/yasam/2021/01/30/ortakoyde-turist-yogunlugu-yagmura-ragmen-istanbuluntadini-cikardilar, Erişim Tarihi: 06.02.2021.

Tayfun, A. ve Yıldırım, M. (2010). Turistlerin tüketim davranışları kültüre/millete göre farklılık gösterir mi? Alman ve Rus turistler üzerine bir araştırma. İsletme Araştırmalarn Dergisi, 2 (2), 43-64.

TRT HABER. (2020). Moskova'dan ilk turist kafilesi İstanbul'a ulaştı, Erişim Adresi: https://www.trthaber.com/haber/gundem/moskovadan-ilk-turist-kafilesi-istanbula-ulasti-506061.html, Erişim Tarihi: 06.02.2021.

Turizm Günlüğü. (2019). İşte ülke ülke türkiye’yi tercih eden turistlerin davranış kalıpları... Erişim Adresi: https://www.turizmgunlugu.com/2019/12/18/turkiyeyi-tercih-eden-turistlerin-davranis-kaliplari/, Erişim Tarihi: 01.02.2021.

Turizm Günlüğü. (2020). Sultanahmet’te turistlerin şikâyet ettiği 4 sorun. Erişim Adresi: https://www.turizmgunlugu.com/2020/09/19/tarihi-sultanahmet-yarimadasi-turizm-sorunlari/, Erişim Tarihi: 01.02.2021.

Tüm dünyanın hayran olduğu şehir İstanbul hakkında 8 ilginç bilgi. (2020, 21 Haziran). Erişim adresi: https://kulturveyasam.com/tum-dunyanin-hayran-oldugu-sehir-istanbul-hakkinda-8-ilginc-bilgi/

Ünal, S. ve Erciş, A. (2006). Pazarın satın alma tarzlarına ve kişisel değerlere göre bölümlendirilmesi. Marmara Universitesi İktisadi ve İdari Bilimler Dergisi, 21(1), 359-382.

Ünal, S., Deniz, A. ve Can, P. (2008). Marka bağllilğ̣1 ve kişisel değerler açısından pazar bölümleme. Atatürk Üniversitesi İktisadi ve İdari Bilimler Dergisi, 22(1), 211-237.

Yıldırım, A. ve Şimşek, H. (2008). Sosyal bilimlerde nitel araștırma yöntemleri. (6. Baskı). Ankara: Seçkin Yayıncılık.

Yıldırım, S. (2013). Tüketicilerin kişisel değerleri ile tüketim değerleri arasindaki ilişkinin incelenmesi (çevre dostu ürün kullanan tüketiciler üzerinde bir araștırma). (Doktora Tezi). Kocaeli Üniversitesi, Sosyal Bilimler Enstitüsü, Kocaeli.

Yılmaz, O. (2018). Turistlerin seyahat motivasyonlarmm bediyelik esyalara yönelik tutumlar ve satın alma niyetleri üzerindeki etkisi. (Yüksek Lisans Tezi). Kurklareli Üniversitesi, Sosyal Bilimler Enstitüsü, Kırklareli.

\section{EXTENDED ABSTRACT}

The problem of this study is that tourists are not trying to understand the world of thought and emotions, some people see tourists only as a source of income, that is, they care about them financially but do not care about them morally, tourist behavior is not considered as personal values-oriented, and because of this situation, tourists are not very satisfied and satisfied personally puts.

One of the important issues in tourism is the effective understanding of tourist behavior and the realization that tourists live in the world of thought and emotion. In order to clarify the inner thoughts and feelings of tourists and to understand their behaviors, an answer is sought to the question of what the behavior of tourists are and how they are evaluated within the framework of personal values.

The purpose of this research; to examine tourist behavior within the framework of Schwartz value system. While carrying out this examination, Istanbul is brought to the fore. With the consideration of tourist behavior, the consequences of tourist behavior, how it can affect tourism movements positively / 
negatively, etc. situations such as are tried to be expressed. It is stated that, thanks to the information that will emerge as a result of the research, positive contributions will be provided to all tourism stakeholders (especially tourists and tourism personnel). It is important to pay attention to communication with tourists, who have a very important position in the tourism sector, and it is emphasized that the necessary measures should be taken in this regard.

In order to achieve more tourist satisfaction, it is important to determine tourist behaviors within the framework of personal values. It is stated that personal values are very effective in tourist behavior, drawing attention to this area will create a different impression (positively) and create awareness. This research enables the understanding of tourist behavior from different aspects by evaluating the behaviors of tourists from both sociological, cultural and touristic perspectives, with a focus on personal values. It is predicted that the study will provide significant convenience at the point of evaluating tourist behavior (especially in terms of sociological, cultural, touristic aspects). Tourism staff can quickly grasp various information about some of the behavior and attitudes of tourists. Personal values are thought to have an important place in a person's life. It is thought that the research will contribute to the creation / increase of the satisfaction and loyalty of the tourists by meeting the demands and needs of the tourists more effectively. The research acts as a source of information for future studies on related issues, and it is stated that it will have very important contributions in shaping new studies on personal value or tourism. The method of the research; qualitative research method, data collection tool of the research; document analysis technique, data analysis technique; it is a descriptive analysis technique.

Personal values are generally stated in the form of the ideas, beliefs and rules of the individual. The values that an individual has, give direction to the purpose of being and his behavior. For this reason, it is one of the important elements in clarifying consumer behavior (Ünal et al., 2008, p. 211). As a matter of fact, in this study, personal values have played an important role in clarifying tourist behavior. It has also emerged as a result that the tourists show an orientation according to their personal values. Parallel to this issue, Schwartz (1994, p. 19-45) stated that personal values determine people's personal orientations and are effective in any choice decision.

Personal values explain what is important in people's lives. In this regard, personal values are numerous and differ from each other. At the same time, people can have many values in different degrees of importance (Bardi and Schwartz, 2003, p. 1207-1220). In this study, it was emphasized which personal values are prominent and important in the behavior of tourists. Consumers behave similarly to their personal values (Erciş et al., 2013, p. 21). In this study, it was revealed that the tourists mostly act according to the personal values they care about.

Within the scope of this research, personal values-oriented tourist behaviors were handled, research findings were classified appropriately, and 10 themes emerged as a result of this classification. It is seen that the personal values of hedonism and tradition come to the fore in tourist behaviors. In this situation, tourists are mostly happy, enjoying and cultural, historical, religious, touristic and so on. Reveals that they aim to satisfy themselves in such terms. A clear understanding of the thoughts, behaviors, feelings and attitudes of tourists is seen as important in ensuring the satisfaction and loyalty of tourists.

This study is limited to the province of Istanbul. From now on, those who will work on the subject are recommended to do their work on the province of Antalya. Also the same subject, located on Turkey's Mediterranean Region can also be adapted onto the provinces. 